\title{
La predicación como prolongación del proyecto salvífico de Cristo en las homilías de Monseñor Romero
}

\author{
Miguel Cavada Diez, \\ Centro de Reflexión Teológica.
}

\section{Introducción}

A Monseñor Romero le hicieron todo tipo de acusaciones: que era predicador de la lucha de clases, instigador político, responsable de la violencia en el país, marxista y comunistal. La razón para estas acusaciones era que Monseñor Romero juzgaba en sus homilfas dominicales los hechos de la vida política, social y económica del país.

A pesar de estas calumnias, sin embargo, y de las presiones del Vaticano, Monseñor Romero nunca dejó a su puebla sin su palabra profética2, habló hasta el final, con lucidez y valentía, de los hechos graves o esperanzadores.que todas las semanas imponfa la realidad, y lo más importante es saber por qué Monseñor Romero predicaba así. La respuesta es, a la vez, sencilla y profunda: si Monsenoor Romero hablaba de la realidad del país y la analizaba a la luz del evangelio, no era por capricho o por exigencias coyunturales, sino porque entendió que eso era, precisamente, la predicación: encamar la palabra de Dios en la realidad de los oyentes.

1. Cfr. Homillas 6 de noviembre de 1977 , I-II, p. $313 ; 9$ de abril de 1978 , IV p. $153 ; 18$ de febrero de 1979. VI p. 213; 10 de junio de 1979, VI p. 387; 26 de agosto de 1979, VII p. 198. Junto a la fecha de la homilía aparece el volumen y página de Mons. Oscar A. Romero, Su pensamiento, 8 volúmenes, San Salvador, 1980-1988.

2. Cinco meses antes de ser asesinado, Monseñor Romero profesó, públicamente y sencillamente, el voto de fidelidad al pueblo: "Quiero asegurarles a ustedes, y les pido oraciones para ser fiel a esta promesa, que no abandonaré a mi pueblo, sino que correré con el todos los riesgos que mi ministerio me exige" (Homilía, 11 de noviembre de 1979. VII, p. 432). 
Si somos sinceros, tenemos que admitir que la mayorfa de las predicaciones de la Iglesia siguen teniendo mucho de exposición doctrinal de la fe cristiana y muy poco de encarnación y actualización de esa doctrina en la realidad histórica de la comunidad que se reúne alrededor de la mesa y de la palabra. Pero precisamente esa encarnación y actualización es la nota específica de la predicación homilética. Sin encarnación de la palabra de Dios en la realidad no hay predicación homilética. Habrá catequesis, habrá exhortación pastoral, habrá exégesis biblica, pero no hay verdadera predicación porque falta lo que es esencial a la homilía: iluminar la realidad histórica con la luz de la palabra de Dios.

Según esto, la finalidad de este artículo es presentar a Monseñor Romero como modelo de predicador y presentar sus homilías como el modelo de verdadera predicación cristiana. Por decirlo desde el principio, que Monseñor Romero hablara de la política, de la economía, de los derechos humanos, de las leyes, de las organizaciones populares, en fin, de los hechos más relevantes del acontecer nacional, es algo que queda justificado, más aún, es exigido, en nombre de una verdad fundamental: Dios sigue salvando en la historia de cada pueblo. Eso es lo que queremos mostrar en este artículo.

En otro lugar hemos analizado en detalle la teologla de la predicación de Monseñor Romero y cuáles son, según él, las notas de la verdadera predicación cristiana3. Ahora queremos profundizar solamente en un elemento de la predicación: cómo expresaba el misterio de la salvación, tal como él lo veía. Y, recordémoslo, este misterio es el que exige que la predicación se encarne en la realidad histórica: "Hemos de ver cada domingo la luz de la palabra que nos guía y. al mismo tiempo, las realidades que nos rodean para iluminarlas"4.

\section{La predicación, prolongación del proyecto salvífico de Cristo}

Si nos preguntamos cuál es mensaje central de las homilias de Monseñor Romero, la respuesta no deja lugar a dudas. Basta leer sus homillas 5 para darse cuenta de que el tema central es la salvación en Cristo, y no podía ser otro, pues la salvación es el núcleo de la fe cristiana. Es cierto que Monseñor Romero

3. Cfr. M. Cavada Diez, "Predicación y profecía. Análisis de Monseñor Romero", en Revista Latinoamericana de Teología 34 (1995), pp. 3-36.

4. Homilia, 26 de febrero de I978, IV, p. 39.

5. El arzobispado de San Salvador ha publicado las homillas de Monseñor Romero en ocho volúmenes que llevan por tílulo Mons. Oscar A. Romero, su pensamiento. Allf están reunidas las homilías dominicales y de festividades litúrgicas desde su nombramiento como arzobispo de San Salvador (f́ebrero de 1977) hasta el día de su asesinato (24 de marzo de 1980). También están publicadas las homillas de mártires y algunas homillas en visitas pastorales, así como mensajes y discursos. Hacen un total de 188 homilías, cinco mensajes y un discurso. 
aborda muchos y diversos temas en la parte doctrinal de sus homilías, pero todo lo expone y lo engloba desde la perspectiva de la salvación.

El mismo Monseñor Romero define la predicación como "una prolongación del misterio salvifico de Cristo". La motivación, contenido y efectos de toda predicación no pueden ser otros, entonces, que la salvación. En la predicación se explica el misterio de la salvación y por la predicación homilética se aplica ese misterio a la realidad concreta de los oyentes. De este modo, la palabra de la predicación se convierte en una palabra que libera:

La predicación del evangelio tiene que ser una prolongación del misterio salvífico de Cristo, una aplicación a nuestra historia, a nuestro pueblo, a nuestra realidad. Una predicación que solamente fuera un cuentecilo romántico de hace veinte siglos y que no tuviera que encarnarse con el proyecto salvífico de Dios en las vicisitudes trágicas, dolorosas o esperanzadoras de nuestra historia, de nuestra realidad, no sería un cristianismo auténtico. ¡Dios sigue salvando en la historia! Es necesario que, a la luz de estas lecturas bíblicas, prolonguemos toda la historia del pensamiento etemo de Dios hasta los hechos concretos de nuestros secuestrados, de nuestros torturados, de nuestra propia triste historia. Es all donde tenemos que encontrar a nuestro Dios (Homilía, 24 de diciembre de 1978, VI, p. 56)6.

Desde esta perspectiva se puede apreciar también la razón de por qué en Monseñor Romero el contenido y el método de la predicación son plenamente unitarios y coherentes. Corno es sabido, sus homilías están divididas fundamentalmente en dos partes: explicación de la palabra de Dios y aplicación de la palabra de Dios a la realidad histórica de los oyentes ${ }^{7}$, es decir, la explicación de las lecturas bíblicas de la liturgia del día y el comentario de los hechos de la semana.

Esta estructura de sus homilías, decíamos, es plenamente coherente con su contenido y finalidad. Primero se explica el misterio de la salvación y después se aplica este misterio a la realidad histórica concreta que le toca vivir al predicador. La predicación es catequesis y profecía. Es catequesis porque en ella se expone el plan salvífico de Dios y es profecía porque en ella se va juzgando la historia actual a la luz de dicho proyecto, de tal manera que se denuncia todo lo que se opone al proyecto de Dios y se anima a todo aquello que está en sintonía con el proyecto salvador. Es lo que hizo Monseñor Romero en todas sus homilías dominicales en catedral, desde la primera hasta la última de cllas.

Hay que insistir en que estas dos partes de sus homilias no están meramente yuxtapuestas. Si a las homilías de Monseñor Romero le quitamos el comentario a los hechos de la semana, es decir, su elemento profético, ya no son homilías,

6. Cfr. Lambién Homilia, 19 de noviembre de 1978, V, p. 304.

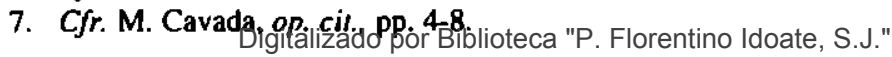

Universidad Centroamericana José Simeón Cañas 
puesto que eliminamos su dimensión histórica; y si no encamamos la palabra de Dios en la realidad histórica, aquélla pierde sus virtualidades salvificas. Dios salva encarnándose en la historia por Cristo, y el mismo dinamismo debe seguir la Iglesia y, por supuesto, la predicación de la Iglesia. Y a la inversa, si a las homilías de Monseñor Romero le quitamos la parte doctrinal, estariamos suprimiendo su dimensión trascendente, y ya no serfa auténtica predicación cristiana. La salvación viene de Dios, y no puede haber una predicación verdadera sin explicación del misterio de Dios.

Aquí está cl secreto de la predicación de Monseñor Romero. Y aunque a algunos les pueda parecer sorprendente, o incluso paradojico, hay que afirmar que su predicación impactó no por ofrecer un contenido nuevo, sino por poner en práclica, con plena coherencia y originalidad, lo que recomienda el magisterio de la Iglesia.

Efectivamente, según el nuevo Derecho Canónico el contenido de la homilía deben ser "los misterios de la fe y las nomas de la vida cristiana" (D.C. 767, \& 1). Dice, además, que la predicación debe exponer "lo que es necesario creer y hacer para la gloria de Dios y salvación de los hombres" (D.C. 768, \& 1), lo que esclarece y concreta remitiéndose a "la doctrina que propone el magisterio eclesial sobre la dignidad y libertad de la persona humana; sobre la unidad, estabilidad y deberes de la familia, sobre las obligaciones que corresponden a los hombres unidos en sociedad; y sobre el modo de disponer los asuntos temporales según el orden establecido por Dios" (D.C. 768, \& 2).

El mensaje de la homilía no debe ser, pues, ajeno a los problemas sociales, cuestión a la que el mismo Derecho Canónico responde con toda claridad: "Compete siempre y en todo lugar a la Iglesia proclamar los principios morales, incluso los referentes al orden social, as! como dar su juicio sobre cualesquiera asuntos humanos, en la medida que lo exijan los derechos fundamentales de la persona humana o la salvación de las almas" (D.C. $747, \& 2$ ).

Según eslos mismos cánones, en la predicación hay dos momentos: la proclamación de los principios y el juicio de la realidad, momentos que siempre deben ir unidos. Pues bien, esto es lo que, ni más ni menos, hizo Monseñor Romero: proclamar la fe cristiana y, a la luz de la fe, emitir un juicio sobre "los asuntos humanos" que le tocó vivir. Lo hizo porque lo exigían "los derechos fundamentales de la persona", tan pisoteados en el momento histórico que le tocó vivir, y en aras de "la salvación de las almas". Monseñor Romero se adelantó, pues, a su tiempo, y puso en práclica lo que el nuevo Derecho Canónico, pocos años después de su martirio, exigirá de todo predicador "siempre y en todo lugar".

Dicho de otra manera, son los predicadores que no aplican el mensaje a la realidad de los oyentes (los hechos de la semana) - y no Monseñor Romerolos que están proponiendo un modo de predicación distinto al que exige la disciplina de la Iglesia y están cayendo en un grave reduccionismo de la fe. En 
lenguaje evangélico, so capa de una mayor espiritualidad y universalismo del mensaje crisliano, "anulan la palabra de Dios" (Mc 7, 13), no hacen lo que Dios hizo: encarnarse para salvar. Y es que según la fe cristiana, no hay salvación sin encamación. No hay verdadera predicación sin actualización de la palabra de Dios en la realidad histórica presente. Pero cuando se da esta actualización, la predicación se convierte en "vehículo" de salvación, es palabra que salva. Y esto lo debieran tener muy en cuenta los predicadores que evitan cualquier comentario y juicio sobre la realidad. Está aquí en juego no sólo una determinada forma o estilo de predicación, sino la fe y la salvación de los oyentes.

Hemos afimado que el misterio de la salvación de Cristo fue el contenido central de las homilías de Monseñor Romero, y lo que justifica su método de predicación. Expliquemos ahora en qué consiste ese misterio de salvación para Monseñor Romero, pues según sea la idea de salvación que tiene el predicador, así será su predicación; según sea su experiencia de Dios, así será el mensaje que transmita.

A continuación vamos a hacer un recorrido por todas las homilías de Monseñor Romero y sistematizaremos las ideas principales de su teología de la salvación. Presentaremos después varios ejemplos de cómo prolonga en la historia el misterio de la salvación. Y, finalmente, sacaremos una importante consecuencia para la predicación. Unas homilías con tanta profundidad teológica y tanta clarividencia profética no se improvisan ni son producto de la casualidad, sino que necesitan preparación. Veremos, pues, cómo Monseñor Romero preparaba sus homilías.

\section{El misterio de la salvación en Cristo}

Quienquiera que se acerque a las homilías de Monseñor Romero con honestidad y sin prejuicios quedará sorprendido por la profundidad y amplitud de su teología de la salvación. Vamos a presentar y analizar el contenido de esa teología, pero antes mencionemos brevemente dos presupuestos fundamentales: la relación entre transcendencia e historia y la relación entre salvación y conflicto.

Por lo que toca a la relación entre transcendencia e historia, Monseñor afirma, por una parte, que la salvación viene de Dios, que fuera de Cristo no hay verdadera salvación y que los creyentes están llamados a colaborar con Dios en su proyecto salvífico. Y por otra -y esto es lo que repite con mayor insistencia-, Monseñor Romero afirma que Dios salva en la historia y que no hay salvación fuera de la historia. La transcendencia no consiste, pues, en salirse de la historia, sino en encarnarse, como Cristo, en la realidad para desencadenar y hacer historia de salvación.

Asimismo, Monseñor Romero enseña que, cuando Dios se encarna definitivamente en la historia a través de Cristo, hace una opción por aquellos a los que la historia ha relegado al último lugar, se inclina a favor de aquellos que en la historia son pobres y oprimidos, de modo que la salvación que Dios otorga en 
Cristo es salvación para los pobres, y desde los pobres es oferta de salvación universal para toda la humanidad.

Por último, Monseñor Romero insiste en que la salvación de Dios pasa por los procesos históricos de liberación. Salvación y liberación son, pues, dos conceptos que van siempre unidos, ya que expresan la misma realidad. Los procesos de liberación no agotan el plan de salvación de Dios; al contrario, necesitan de Dios para humanizarse y plenificarse, para ser verdaderamente procesos de liberación. Pero, como ya queda apuntado, el plan salvífico de Dios tampoco es posible sin mediaciones históricas, procesos históricos de liberación, que serán tanto más transcendentes cuanto más encarnen "el pensamiento de Dios" en la realidad histórica.

Por lo que toca a la relación entre salvación y conflicto, Monseñor Romero comprendió a cabalidad que el plan de salvación de Dios no es ajeno al conflicto histórico, y esto Monseñor Romero lo explicó con toda claridad. EI plan de salvación entra en conflicto con los ídolos del mundo -ídolos de la opresiónporque no se pueden reconciliar salvación y opresión, Dios e fdolos. De este modo, la salvación implica un quehacer negativo, "quitar el pecado del mundo", lo cual, a su vez, exige ante todo tomar en serio ese pecado que da muerte y somete a condenación histórica a miles de seres humanos. Pues bien, no es posible "quitar el pecado del mundo" sin entrar en conflicto con los que en el mundo causan el pecado que da muerte. Implica también un quehacer positivo, "anunciar la buena nueva" de la liberación a los pobres, ser "libres para Cristo". Pero eso es también conflictivo puesto que choca con la práclica de los poderosos que no quieren buenas noticias para los pobres y hacen al ser humano "esclavo de los ídolos opresores".

Historia y transcendencia, encarnación y pobres, liberación y pecado, anuncio y conflicto, son pues los conceptos fundamentales de la teología de la salvación que Monseñor Romero expone en sus homilías. La salvación es el mismo Dios que se encarna en la historia para liberar a los pobres del poder del pecado y, desde ellos, redimir a toda la humanidad.

Esto es lo que vamos a exponer a continuación, ofreciendo abundantes citas de las homilías de Monseñor Romero. Y lo hacemos así, porque nada mejor que sus propias palabras para esclarecer el tema.

\section{1. "Dios quiere salvar en la historia"}

“¿Qué consuelo da saber que Dios va con nosotros en la historia!"B. Dios "se hace caminante con los hombres en la historia de todos los pueblos"9. Estas

8. Homilia, 9 de diciembre de 1979, VIII, p. 13.

9. Ibid., VIIl, p. 15. 
expresiones de Monseñor Romero resumen su profunda fe en el Dios que está cerca, presente en la historia. Por la fe, los creyentes deben "descubrir la mano de Dios en las coyunturas históricas del pueblo"10. Eso es lo que hizo Monseñor: indicar los caminos por donde Dios llega a la humanidad. Por eso enseñó que la historia necesita una teología: en la historia está Dios, hay que buscarlo en los acontecimientos históricos de la actualidad y no en otro lugar. La historia es el lugar privilegiado donde Dios ha querido salir al encuentro de quien quiera buscarlo:

Esta historia necesita una teología. Es la teología de la historia que hasta en los hechos triviales y concretos, hasta en los hechos criminales, encuentra algo de Dios... Dios habla desde la historia, Dios reclama desde lo bueno y bello que hay dentro de los hombres, como también reclama ante lo feo y lo malo que hay en las sociedades, que hay en los hombres (Homilía, 18 de febrero de 1979, VI, p. 153).

¿Ven como los acontecimientos de los pueblos los aprovecha la historia de salvación para sembrar en los hombres la esperanza, el arrepentimiento, el retomo a Dios, la alegrla de sentirse acompañados por Dios en la historia? Dios va con nuestra historia. Dios no nos ha abandonado. Dios va sacando partido hasta de las injusticias de los hombres esperando el retorno... Hagamos lo posible para que nuestra historia salvadoreña sea de verdad una historia de salvación (Homilía, 9 de diciembre de 1979, VПI, p. 18).

Por eso, la tarea del predicador no es, en principio, explicar la palabra de Dios escrita, sino señalar los caminos de la historia por donde Dios sale hoy al encuentro de la humanidad, aunque, obviamente, la Sagrada Escritura sigue siendo la ayuda insustituible para discernir la presencia y la actuación de Dios en el hoy y ahora:

Si esto, nuestras vidas, la historia de nuestro pueblo, son los caminos concretos por donde Dios está saliendo hoy, en 1978, a salvar a los salvadoreños, es necesario conocer estos caminos. Por eso mi preocupación de que esta predicación del evangelio no se desencarne, que la predicación de este domingo ilumine las realidades de nuestra semana (Homilia, 10 de diciembre de 1978, VI, p. 32).

Y Dios está en la historia para salvar. "Dios quiere salvar en la historia, los salvadoreños nos salvaremos en nuestra historia nacional"1I. "Dios quiere salvar a El Salvador"I2. La salvación es un hecho histórico y hay que buscarla en los

10. Homilia, 23 de marzo de 1980, VIIl, p. 368; cfr. también Homilia, 16 de julio de 1978, v p. 72.

11. Homilia, 11 de diciembre de 1977, III, p. 58; cfr. tambiến Homilia, 9 de diciembre de 1979. VIIl, p. 17.

12. Homilia, 11 de diciembre de 1977, III, p. 58. 
hechos históricos. Esto significa que la salvación no se reduce a una relación de intimidad entre Dios y cada persona (con lo cual no se está negando la relación personal con Dios) y significa también que la salvación no es algo que acaece más allá de la historia, en la etemidad. Hay que buscar a Dios y la salvación que nos ofrece "alll donde la debemos de buscar", en los hechos históricos:

La salvación es un hecho histórico, no del pasado, sino de la historia presente de cada pueblo, de cada hombre, de cada comunidad. Y esto es interesante que lo tengamos muy en cuenta. Porque los hechos históricos, si nosotros los enfocamos directamente semana a semana, no es por un afán de salimos del evangelio y de la mente de la Iglesia, sino para que esa salvación que Dios esıá haciendo de los salvadoreños, encarnada en su propia historia, la busquemos allí donde la debemos de buscar, en nuestros hechos históricos... El reino de Dios, que se va construyendo en la historia, tiene que chocar con realidades históricas, y esto no es meterse en política, sino simplemente es buscar la salvación de Dios en nuestra historia (Homilia, 19 de noviembre de 1978, V, p. 304).

Por lo que ya se ha expuesto, es fácil deducir que para Monseñor Romero no hay dos historias, una, la historia sagrada, y otra, la historia profana; dos historias que serían paralelas y que nunca convergerían. No hay dos, sino solamente una historia 13, que Dios quiere convertir en historia de salvación, pero que, por el pecado del mundo, puede ser historia de condenación:

Uno de los cambios de la Iglesia actual es haber roto esa dicotomía, esa separación entre la Iglesia y el mundo, porque también ha comprendido la unidad de la historia profana con la historia de la salvación... Había una separación casi infranqueable entre lo material y lo espiritual, entre lo profano y lo sagrado, y se aconsejaba una especie de conformismo: pasemos la vida, la historia, como se pueda, y ya vendrá el cielo y la salvación eterna, procuremos no condenarnos en el infierno. $Y$ así teníamos a la historia algo separada de nosotros... Dios tiene un designio para salvar a los hombres, precisamente valiéndose de su historia profana. Es en la historia de su pueblo de lsrael donde Dios va tejiendo su designio de salvación, y ese paradigma se realizará en las historias de todos los pueblos. La historia de $\mathrm{El}$ Salvador, con sus próceres, con su polftica, con sus propias lacras, con sus propias cosas buenas, con sus preocupaciones, es la historia de los salvadoreños, y en esa historia de los salvadoreños es donde Dios quiere encontrarse con los salvadoreños y salvarlos (Homilia, 7 de agosto de 1977, I-II, Pp. 161-162).

La misión de la Iglesia no es, pues, hacer una historia sagrada al margen de la historia secular, separando a los hombres del mundo y abandonando a éste a

13. Homilia, 9 de diciembre de 1979, VIII, p. 21. 
su propia suerte. Su misión es, más bien, hacer de la única historia que existe una historia de salvación y no una historia de perdición:

Este es el Dios verdadero, el Dios vivencial, el Dios de Moisés, el Dios de la historia, que no solamente salva en la historia de Israel, sino que salva en la historia de El Salvador, y ha puesto una Iglesia para que proclame esa fe en el Dios verdadero y purifique de pecado la historia y santifique la historia para convertirla en vehículo de salvación. Esto quiere la Iglesia de El Salvador: hacer de nuestra historia no una historia de perdición, de ateísmo, no una historia de abusos y de injusticias, sino hacer una historia que corresponda a los ideales de Dios que ama a los salvadoreños (Homilía, 21 de mayo de 1978, IV, p. 255).

No hay contradicción entre lo humano y lo cristiano, lo natural y lo sobrenatural. Y en esa misma línea afirma Monseñor Romero que asl como la salvación que Dios trae no se realiza fuera de la historia, asf tampoco se realiza al margen de lo humano, porque "el cristianismo no viene a quitarnos nada de lo humano"14, sino a llevar lo humano a su plenitud:

Antes de ser cristiana, la sociedad tiene que ser humana... Hermanos, todo lo que es verdadero, noble, justo, puro, amable, laudable, todo eso tenedlo en cuenta. Ya no es tiempo, queridos hermanos, de vivir esa dicotomía entre lo creado y lo redimido (Homilía, B de octubre de 1978, V, p. 230).

No es sembrar aquí la discordia. Simplemente es gritar al Dios que Ilora, el Dios que siente el lamento de su pueblo porque hay mucho alropello, el Dios que siente el lamento de sus campesinos que no pueden dormir en sus casas porque andan huyendo de noche, el lamento de los niños que claman por sus papás que han desaparecido: ¿dónde están? No es eso lo que esperaba Dios, no es una patria salvadoreña como la que estamos viviendo lo que debla ser el fruto de una siembra de humanismo y cristianismo (lbid., V, p. 233).

La historia es, en definitiva, historia de Dios, pero para Monseñor Romero, en cuanto creyente cristiano, hay que hacer una precisión esencial: esa historia de salvación se hace presente fundamentalmente en Jesús y en su historia concreta. Jesús anuncia y realiza el reinado de Dios, que es "buena noticia" de justicia y liberación para los pobres, reinado que es la intervención misericordiosa de Dios para rescatar a la humanidad del poder del pecado. El punto culminante de la historia de Jesús y el de toda la historia es la muerte y resurrección de Jesús:

La muerte y resurrección son el momento culminante de toda la historia. Si los pueblos y los hombres se salvan, es porque deriva la salvacion de esa muerte y de esa resurrección. Por eso, los cristianos sabemos que la transfor-

14. Homilía, 8 de octubre de 1978, V. p. 23 
mación de nuestro país ya está decretada en Cristo el redentor. Y los cristianos sabemos que el mundo, por más horrorosas tinieblas que se ciernen sobre él, ya está amaneciendo a la claridad de la verdadera rendención desde el día en que Cristo murió y resucitó (Homilía, 11 de noviembre de 1979. VII, p. 429).

La historia de Jesús se prolonga en nuestra historia. Dios nos entrega el Espíritu de Jesús resucitado para continuar su obra salvffica y "recapitular todas las cosas en Cristo". También nosotros tenemos que construir la historia de salvación:

La historia de la salvación la va haciendo Dios en la historia de cada pueblo... Y el Dios de nuestros pueblos pobres también está construyendo la historia de la salvación con historia salvadoreña y no con historias postizas. La historia que el Espíritu Santo anima tiene para el pueblo cristiano un motivo maravilloso y se llama: la resurrección. El Espíritu que resucitó a Cristo nos ha dado, en ese Crislo resucitado, el modelo de la historia. Hacia allá tienen que caminar todas las historias, a hacer hombres que, después de vivir con su cruz a cuestas, resuciten a la libertad que ya se debe saborear también en esta tierra, pero que no se tendrá definitiva hasta que disfrutemos la plenitud del reino de Dios. No quiere decir esto que vamos a dejar la liberación del pueblo para más allá de la muerte. Estoy diciendo que Cristo resucitado pertenece ya a la historia presente y que es fuente de libertad y de dignidad humana... Cristo es nuestro, Cristo es salvadoreño para los salvadoreños, Cristo ha resucitado aquí en El Salvador para nosotros, para buscar desde la fuerza del Espíritu nuestra propia idiosincrasia, nuestra propia historia, nuestra propia libertad, nuestra propia dignidad de pueblo salvadoreño (Homilia, 24 de febrero de 1980, VIII, p. 266).

De este modo, un elemento esencial de la salvación es proseguir en la historia la tarea de Jesús, anunciar y realizar en ella el reino de Dios. El reino de Dios es, así, el criterio para discernir, juzgar y actuar en la historia:

Ustedes mismos, analizando esta palabra de Dios tan providencial que se nos ha dado hoy, vean qué cosas hay en nuestra Iglesia y en nuestra historia que van reflejando en El Salvador la historia de la salvación de Dios. Y, al revés, qué cosas puede haber en nuestra historia salvadoreña y aún dentro de nuestra Iglesia salvadoreña, que no reflejen ese reino de Dios y que, por tanto, tenemos que arrancarlo como pecado. Porque pecado es todo aquello que se opone al designio salvador de Dios en la historia (Homilía, 9 de diciembre de 1979, VIII, p. 22).

"Dios quiere valerse de los hombres para salvar al mundo"15. La salvación

15. Homilla, 9 de diciembre de 1979, V1li, p. 15. 
es iniciativa de Dios, pero Monseñor insiste en que Dios quiere la colaboración de los hombres para hacer real e histórico su plan de salvación:

¿Qué hace Israel en las coyunturas de su historia? Primero, encuentra a Dios en su historia; $y$, segundo, siente que hay una alianza entre el Dios de la historia y él, el hombre, el israelita artífice de su historia. Y entre los dos, Dios y el hombre, porque han hecho una alianza de liberación, liberan al pueblo siempre. Nunca sólo el hombre, nunca s6lo Dios. Dios y el hombre van haciendo la historia. La mejor flor de esa pedagogía es Cristo (Honilía, 11 de noviembre de 1979, VII, p. 420).

Hemos visto en estos textos que, según Monseñor Romero, la salvación es iniciativa de Dios, que esta salvación es histórica por cuanto se realiza en la historia y desencadena una historia, y que el momento culminante de esta historia es la encarnación, muerte y resurrección de Jesús. Pero todavía no se ha concretado algo fundamental: cómo realiza Dios la salvación y a quiénes dirige Dios la salvación.

\section{2. "Dios quiere salvar a los hombres como pueblo"}

"No nos podemos salvar solos. Dios quiere salvar a los hombres como pueblo"I6. Monseñor Romero insiste en que salvación y pueblo son dos realidades inseparables, tal como aparece en la Escritura, en el Vaticano II y en la teología de la liberación. El plan de salvación de Dios es formar un pueblo: "Ustedes serán mi pueblo y yo seré su Dios" (Ez 11, 20), y, por ello, la Biblia es la historia de la relación de Dios con el pueblo, de modo que incluso la relación personal de Dios con Moisés y los profetas está siempre refererida al pueblo. También el Vaticano II define a la Iglesia como "el pueblo de Dios" al servicio de la humanidad, siendo su misión la de congregar a todos los pueblos en un sólo pueblo. Por último, la teología de la liberación presenta a las grandes mayorías, que viven postradas en la miseria y la pobreza, como el "pueblo crucificado", que prolonga en la historia la pasión de Jesús y que, a la vez, salva a la humanidad 17. El concepto pueblo es, pues, fundamental en la soteriologla, y en ello insiste Monseñor Romero: Dios quiere salvar al pueblo, pero no como pura colectividad, como masa, sino en cuanto verdadero pueblo, con conciencia de pueblo:

Quiere Dios salvamos en pueblo. No quiere una salvación aislada. De ahí que esta Iglesia de hoy, más que nunca, esté acentuando el sentido de pue-

16. Homilia, 11 de junio de 1978, V, p. 27; clr. Lambiên Homilía, 23 de marzo de 1980 , VIII. pp. 364-367.

17. Cfr. I. Ellacuría, "El pueblo crucificado. Ensayo de soteriología histórica" en Revisıa latinoamericana de Teología 18 (1989), pp. 305-333. 
blo. Y por eso, la Iglesia sufre conflictos porque la Iglesia no quiere masa, quiere pueblo. Masa es el montón de hombres, cuanto más adormecidos, mejor; cuanto más conformistas, mejor... La Iglesia quiere despertar a los hombres en el verdadero sentido de pueblo. ¿Qué es pueblo? Pueblo es una comunidad de hombres donde todos conspiran al bien común (Homilia, 15 de enero de 1978, III, pp. 151-152).

El mismo Monseñor Romero traduce pastoralmente esta verdad, enseñando que la misión de la Iglesia es hacer de la masa un pueblo, y del pueblo el pueblo de Dios18. En este sentido, es verdad que para él "fuera del pueblo no hay salvación", la salvación no es una realidad individual y espiritualista19. Esta crítica al individualismo como camino para la salvación es muy clara en la predicación de Monseñor Romero:

El Verbo se hizo carne y quiere vivir no en individuo. Esto, por favor, tengámoslo muy en cuenta, que es causa de un conflicto muy grande en la Iglesia de hoy: el cambio de una piedad individualista a una piedad comunitaria. Ya no es tiempo de decir: "yo trato de salvarme, no me importan los demás". Porque si no te salvas con otros, puede ser que no te salves tú solo. La salvación que Cristo ha traído es en comunidad (Homilia, 17 de diciembre de 1978, VI, p. 47).

Lamentablemente, queridos hermanos, somos el prodscto de una educacion espiritualista, individualista, donde se nos enseñaba: "Procura salvar tu alma y no te importe lo demás". Cómo decíamos al que sufría: "Paciencia, que vendrá el cielo, aguanta". ¡No! No puede ser eso. Eso no es salvar, no es la salvación que Cristo trajo. La salvación que Cristo trae es la salvación de todas las esclavitudes que oprimen al hombre... Es necesario que el hombre, que vive bajo el signo de tantas opresiones y esclavitudes -el miedo que esclaviza los corazones, la enfermedad que oprime los cuerpos, la preocupación, el terror que oprime nuestra libertad y nuestra vida-, rompa todas esas cadenas. ¡Por aht hay que comenzar! (Homilia, 9 de septiembre de 1979, VII, p. 237).

La revelación es la "autodonación de Dios" y Dios se dona a sí mismo, liberando al pueblo de la esclavitud en Egiplo y liberando a la humanidad del poder del pecado en la cruz de Jesús. "Así es Dios", y por ello el encuentro personal con Dios sólo es posible siguiendo los caminos de Dios. Solamente si hacemos lo que Dios hace y como Dios lo hace, es posible encontramos con Dios allí donde él quiso dejarse encontrar: en el pueblo. "La seguridad sólo es Dios, a nosotros sólo nos toca seguir humildemente por donde Dios nos quiere

18. Cfr. Misión de la Iglesia en medio de la crisis del pais, Cuarna Carta Pastoral de Monseñor Romero, Arzobispado de San Salvador, agosto de 1979, n. 89.

19. Cfr. Homilia, 30 de julio de 1978, V, p. 101. 
Ilevar"20. La salvación exige ponerse en camino, desinstalarse, acompañar al pueblo, identificarse con sus sufrimientos y quitar el pecado del mundo que causa ese sufrimiento:

El que quiera salvar su alma, es decir, en frase bíblica, el que quiera estar bien, el que no quiera tener compromisos, el que no se quiere meter en líos, el que quiere estar al margen de una siluación donde todos tenemos que comprometemos, ése perdera su vida. ¡Qué cosa más horrorosa haber vivido bien cómodo sin ningún sufrimiento, no metiéndose en problemas, bien tranquilo, bien instalado, bien relacionado políticamente, económicamente, socialmente! Nada le haća falta, todo to tenía. ¿De qué sirve? Perderá su alma. Pero el que por amor a mí, se desinstale y acompañe al pueblo, y vaya en el sufrimiento del pobre, y se encame y sienta suyo el dolor, el atropello, éste ganará su vida, porque mi Padre lo premiará (Homilía, I de abril de 1979, VI, p. 249)2I.

\section{3. "Se hizo pobre para salvar a los pobres y para salvar, desde los pobres, a toda la humanidad"}

Dios, por Cristo, "salva a través de los pobres a todo el que quiera salvarse"22. Esta frase de Monseñor Romero es central en su pensamiento y resume lo que trataremos de sistematizar en este apartado. Si bien es cierto que la oferta de la salvación es universal —Dios quiere salvar a todos 23 , también es cierto que Dios quiere salvar desde los pobres, porque "entre los pobres quiso poner Cristo su cátedra de redención"24.

Muchos afirman lo primero, pero ignoran y hasta niegan lo segundo. Sin los pobres la salvación pierde su carácter histórico y universal, se torna intimista e individual. Si antes decíamos que fuera del pueblo no hay salvacion, ahora debemos añadir, para completar y precisar más dicha afirmación, que fuera de los pobres no hay salvación: extra pauperes nulla salus. Los pobres no solamente son aquellos a quienes hay que salvar de la injusticia opresiva y represiva que los deshumaniza, sino que los pobres son aquellos que, puesto que cargan con el pecado de la humanidad, la salvan. Es por eso que Monseñor Romero predicó a tiempo y a destiempo, oportuna e inoportunamente, que Cristo está presente en los pobres y que no hay verdadero cristianismo si no hay una clara opción preferencial por los pobres.

20. Homilía, II de junio de 1978, V, p. 27.

21. Cfr. tambien Homilia, 16 de septiembre de 1979, VII, p. 266.

22. Homilla, 17 de febrero de 1980, VIII, p. 242.

23. Cfr. Homilia, 15 de enero de 1978, III, p. 151.

24. Homilia, 24 de diciembre de 1978, VI, p. 76. 
Cuando Monseñor Romero rebate a aquellos que quieren "conservar un evangelio tan desencarnado que no se mezcla en nada con el mundo que tiene que salvar" argumenta que, queramos o no, "Cristo ya está en la historia, Cristo ya está en la entraña del pueblo, Cristo ya está operando los cielos nuevos y la tierra nueva"25. No es casualidad que el texto brblico que Monseñor Romero más cita en sus homilías es Mateo 25, $31-46$ (el juicio final). La presencia de Cristo en los pobres es central en la teología de la salvación de Monseñor Romero. La Iglesia es "sacramento universal de salvacion" en cuanto se configura como Iglesia de los pobres26, porque éstos son el sacramento de Cristo en la historia:

Es inconcebible que se diga alguien cristiano y no tome, como Cristo, una opción preferencial por los pobres... Cuando decimos "por los pobres", no nos parcializamos hacia una clase social, Ifjense bien. Lo que decimos como dice Puebla- es una invitación a todas las clases sociales, sin distinción de ricos y pobres: tomemos en serio la causa de los pobres como si fuera nuestra propia causa, más aún, como de verdad es, la causa de Jesucristo que en el día del juicio final pedirá que sólo se salven los que atendieron al pobre con fe en él. Todo lo que hicisteis a uno de estos pobrecilos, marginados, ciegos, cojos, sordos, mudos, a mí me lo hicisteis (Homilia, 9 de septiembre de 1979, VII, p. 236).

Ya vimos que Dios salva a la humanidad desde la entraña de la historia, que Dios está en la historia. Por eso, la transcendencia no es salirse de la historia, no es "escapar del mundo", sino justamente lo contrario. Transcender es encarnarse en la historia y, desde dentro, redimirla, hacerla avanzar según los designios de Dios. Pero aún más, la transcendencia es encarnarse en la realidad de aquellos que la historia ha marginado, los pobres. La transcendencia es meterse y comprometerse con los pobres, es hacer la opción preferencial por los pobres. Monseñor Romero lo explica con toda claridad:

Digo en mi cuarta carta pastoral: la transcendencia que la Iglesia predica no es una alienación, no es irse al cielo a pensar en la vida eterna y olvidarse de los problemas de la tierra. Es una transcendencia desde el corazón del hombre. Es meterse en el nin̄o, meterse en el pobre, meterse en el andrajoso, en

25. Cfr. Homilía, 3 de diciembre de 1978, VI, p. 14.

26. En las obras $L a$ voz de los sin voz. La palabra de Monseñor Romero (San Salvador 1980), pp. 311-316 y Monseñor Romero. El pueblo es mi profela (San Salvador 1994) pp. 69-76 se pueden encontrar varios fragmentos de las homilías de Monseñor Romero sobre este tema. No se puede reflexionar sobre la salvación sin reflexionar, a la vez, sobre la Iglesia, "el sacramento universal de salvación". Sin embargo, el pensamiento de Monseñor Romero sobre la Iglesia, que fue otro de los grandes temas que explicó en la parte doctrinal y catequética de sus homilfas, requiere un estudio más exhaustivo. 
el enfermo, en la cabaña, en la choza, es ir a compartir con él. Y desde la entraña misma de su miseria, de su situación, transcenderlo, elevarlo, promoverlo y decirle: tú no eres una basura, tú no eres un marginado. Es decirle cabalmente lo contrario: tú vales mucho, tú vales tanto como el señor que vive en las grandes moradas que tú ves y no podrás poseer. Tú eres igual, tú eres hombre como todos, imagen de Dios, estás llamado también al cielo. Esta es la uranscendencia que da la verdadera dimensión de los grandes (Homilía, 23 de septiembre de 1979, VI, p. 286).

$\mathrm{Y}$ volvemos aquí a la opción preferencial por los pobres. No es demagogia. Es evangelio puro. Si no nos preocupamos de los intereses del pobrecito, del pequeñuelo, pero no de cualquier modo, sino porque representa a Jesús, por la fe que abre el humilde, el marginado, el pobre, el enfermo, mirar en él a Jesús, ésa es la transcendencia. Cuando no se mira más que un rival, un imprudente, alguien que viene a aguarme mis fiestas, naturalmente el pobre estorba. Pero cuando se abraza, como abrazó Cristo al leproso y cuando levanta el buen samaritano al herido del camino, porque lo que le haga a él se lo hace a Cristo, ésta es la transcendencia, sin la cual no es posible una perspectiva de justicia social. Cristo presente en los pequeñitos (Homilía, 30 de septiembre de 1979, VII, p. 314).

Cuando Monseñor Romero asumió y predicó esta opción preferencial por los pobres, la respuesta fue fulminante: los ricos lo odiaron hasta la muerte. Esto no debe extrañamos, pues la misma respuesta recibió Jesús. A Monseñor Romero lo acusaron de ser partidarista y de "hacer política" desde el púlpito. Sus detraclores se mofaban de él llamándole "Marxnulfo Romero". Pero que los ricos lo odiaran, no fue obstáculo para que él, fiel a la voluntad de Dios, los siguiera llamando "queridos capitalistas"27, porque efectivamente les revelaba el amor universal de Dios:

¿Por qué "Iglesia de los pobres"? ¿Que acaso los ricos no tenemos alma? Claro que sí. Y los amamos entrañablemente y desearnos que se salven, que no vayan a perecer aprisionados en su propia idolatría, les pedimos espiritualizarse, hacerse almas de pobres, sentir la necesidad, la angustia del necesitado (Homilía, 15 de octubre de 1979, v, p. 250).

Cuando la Iglesia se proclama Iglesia de los pobres como que se parcializa y desprecia a los ricos. ¡De ninguna manera! El mensaje es universal. Dios quiere salvar a los ricos también, pero precisamente porque los quiere salvar, les dice que no se pueden salvar mientras no se conviertan al Cristo que vive precisamente entre los pobres (Homilia, I de julio de 1979, VII, p. 49).

En presencia de la desigualdad e inequidad, Monseñor Romero afirmó, en

27. Cfr. Homilía, 25 de marzo de 1979, VI, p. 230. 
una atinada expresión, que se debe hacer "política de Dios"28, que consiste en buscar la justicia y la igualdad entre las personas:

Política de Dios. Esta si es la política verdadera: la que trata a los hombres no como hombres de primera clase y de segunda clase, sino la que dice: no puede haber acepción de personas en aquel que cree en el glorioso Señor Jesucristo, encarnado en la miseria de los hombres (Homilia, 9 de septiembre de 1979, VII, p. 236).

Particularmente importante para nuestro tema es la homilía que lleva por título: "La pobreza de las bienaventuranzas, fuerza de la verdadera liberación del pueblo"29. El título ya lo dice todo. No podemos hablar de la salvación en Cristo eludiendo la pobreza y a los pobres. En la parte doctrinal de esta homilía, Monseñor Romero predica que la pobreza es una denuncia divina, un espiritu y un compromiso. Veámoslo un poco más en detalle.

\subsubsection{La pobreza es pecado que hay que denunciar}

La salvación cristiana, que se realiza en la historia, comienza por reconocer en la pobreza la denuncia de Dios contra el pecado que mata al pueblo. La pobreza es un mal, no es voluntad de Dios, sino denuncia del Dios de los pobres contra los poderosos de este mundo. Además, la pobreza no se supera con más desarrollo y progreso. Este planteamiento es ingenuo y falaz, pues cuanto más desarrollo y progreso hay en la humanidad, más pobreza existe. La pobreza se supera erradicando sus causas: la injusticia social, a la que Monseñor Romero llama pecado mortal, por cuanto da muerte. La pobreza es muerte para la inmensa mayoría de la humanidad:

¿Por qué hay pobres? ¿Por qué hay gente que tiene hambre? ¿Por qué hay gente que sufre? ¿Esos, que son bienaventurados, por qué sufren, por qué lloran, por qué tienen hambre, por qué existen? Es tremendo el evangelio de hoy cuando señala las causas de esas carencias: "¡Ay de vosotros los ricos, porque ya tenéis vuestro consuelo! ¡Ay de vosotros los que estáis saciados porque tendréis hambre! ¡Ay de los que ahora reís porque haréis duelo y lloraréis!". Resuena en la voz de Cristo el acento de todos los profetas del Viejo Testamento. ¡Qué tremendos son los profetas cuando denuncian a los que juntan casa con casa y a los que juntan terrenos y terrenos, se hacen

28. Esta expresión aparece en dos ocasiones en las homilías de Monseñor Romero, con signilicados diferentes, pero relacionados. Primero, la politica de Dios es no eludir el sufrimiento como camino para salvar el mundo, cfr. Homilia. 16 de abril de 1978, IV p. 173, concepto fundamental en la soteriología que Monseñor Romero expone y que abordaremos enseguida. El segundo significado es el que señalamos ahora cn el texto.

29. Homilía, 17 de febrero de 1980, VIII, pp. 229-252. 
dueños de todo el país! La existencia, pues, de la pobreza, como carencia de lo necesario, es una denuncia. Hermanos, quienes dicen que el obispo, la Iglesia, los sacerdotes, hemos causado el malestar en el país, quieren echar polvo sobre la realidad. Los que han hecho el gran mal son los que han hecho posible tan horrorosa injusticia social en que vive nuestro pueblo. Los pobres han marcado, por eso, el verdadero caminar de la Iglesia. Una Iglesia que no se une a los pobres para denunciar desde los pobres las injusticias que con ellos se cometen, no es verdadera Iglesia de Jesucristo (Homilía, 17 de febrero de 1980, VIII, p. 233)30.

La pobreza denuncia el pecado. En su acercamiento a los pobres la Iglesia comprende que el pecado es cosa grave. Pecado es aquello que dio muerte al Hijo de Dios y pecado sigue siendo aquello que da muerte a los hijos de Dios. Esa verdad fundamental de la fe, la vemos a diario en situaciones de nuestro país. No se puede olender a Dios sin ofender al hermano. No es, por ello, pura rutina que repitamos una vez más la existencia de unas estructuras de pecado en nuestro país. Son pecado porque producen los frutos del pecado, la muerte de los salvadoreños, la muerte rápida de la represión o la muerte lenta de la opresión estructural. Por ello hemos denunciado el pecado de la injusticia (Ibid., VIII, p. 235).

\subsubsection{La pobreza es un espíritu}

"Sin pobreza de espíritu no puede haber llenura de Dios"३1. Monseñor Romero acepta y valora grandemente la expresión "pobres de espíritu", pero aclara que ha sido tergiversada "hasta el modo de querer decir que todos son pobres, hasta el que está oprimiendo a los demás. No es cierto"32. Para Monseñor, la pobreza material es condición para sentir la necesidad radical de Dios, y esto sucede cuando el pobre convierte su pobreza no en fatalismo y sometimiento, sino en fuerza de liberación. La pobreza de espíritu33 significa tomar "conciencia", conciencia de la presencia de Dios en los pobres, que quiere salvar al mundo desde los pobres. Ya alguien dijo que hay pobres con conciencia de ricos, es decir, los que esperan salir de la pobreza imitando al rico.

La salvación necesita de pobres con conciencia de pobres, pobres que conocen las causas de su pobreza, que creen en sus hermanos pobres y que comprenden que la tarea no es salir "ellos" de la pobreza, sino erradicar la pobreza

30. Cfr. también Homilia, 16 Je diciembre de 1979, VIII, pp. 46-47.

31. Homilia, 24 de diciembre de 1978, VI, p. 62.

32. Homilia, 17 de Tebrero de 1978, VIII, pp. 237-238.

33. I. Ellacurfa tradujo la expresion "pobres de espíritu" por "pobres con espíritu", cfr. Conversión de la Iglesia al reino de Dios para anunciarlo y rgalizarlo en la listaria (San Salvador 1985) p. 151. 
misma yendo a la raiz del mal. Es lo que expresa la conocida canción de la Misa Popular Salvadoreña: "Cuando el pobre crea en el pobre es que el reino de Dios ya empezó". La pobreza de espíritu es "llenura" del espíritu de Jesús de Nazaret:

La pobreza es, pues, una espiritualidad, es una aclitud del cristiano, es una disponibilidad del alma abierta a Dios... No es una pobreza simplemente material, no tener nada, y eso es malo. Es una pobreza que toma conciencia, es una pobreza que acepta la cruz y el sacrificio no con conformismo, porque sabe que no es eso voluntad de Dios. Pero sabe también que en la medida en que hace de su pobreza una conciencia, una espiritualidad, una entrega, una disponibilidad al Señor, se está haciendo santo y desde una santidad sabrá ser el mejor liberador de su propio pueblo. La Iglesia está forjando estos liberadores del pueblo. Ustedes cristianos, en la medida en que su pobreza se convierte en espiritualidad, en esa medida también ustedes son liberadores de nuestro pueblo (Homilía, 17 de febrero de 1980, VIU, pp. 236-237).

Estos son los verdaderos pobres, la espiritualidad de los pobres sustancialmente es una gran confianza en el Señor, y la maldición de los ricos es cuando se apartan del Señor y ponen toda su confianza en la carne, es decir, en los valores terrenales. Por eso, hermanos, no es un prestigio para la Iglesia estar bien con los poderosos. Este es el prestigio de la Iglesia: sentir que los pobres la sienten como suya, sentir que la Iglesia vive una dimensión en la tierra llamando a todos, también a los ricos, a convertirse y salvarse desde el mundo de los pobres, porque ellos son únicamente los bienaventurados (Ibid., VIII, p. 239).

\subsubsection{La pobreza es un compromiso}

Finalmente, de la pobreza se desprende para Monseñor Romero un compromiso. Se trata del seguimiento de Jesús, como norma de toda vida cristiana, pero concretando ese seguimiento desde la pobreza. Pobreza es, entonces, solidarizarse con los pobres y con ellos redimir al mundo de la muerte y el pecado:

Este es el compromiso de ser cristiano: seguir a Cristo en su encarnación. $Y$ si Cristo es Dios majestuoso, que se hace hombre humilde hasta la muerte de los esclavos en una cruz y vive con los pobres, asi debe ser nuestra fe cristiana. El cristiano que no quiere vivir este compromiso de solidaridad con el pobre, no es digno de llamarse cristiano (Homilia, 17 de febrero de 1980, VIII, p. 240).

En la segunda leciura de hoy, también se confirma esta verdad de la pobreza como compromiso. Las manifestaciones extremas de la pobreza son el pecado y la muerte. No hay gente más miserable que el que está en pecado, y no hay ser más pobre que un cadáver. A esto se comprometió Cristo, a los pecadores y a los muertos. Y por eso la redención de Cristo señala a todas 
las liberaciones de la tierra que están mancas, que no están completas, mientras no logren liberar también del pecado a los pecadores, y de la muerte a los muertos. Y eso ofrece el gran liberador. Dichosos los que trabajan las liberaciones políticas de la tierra teniendo en cuenta la redención de aquel que salva del pecado y salva de la muerte (Ibid., VIII, p. 24I).

\section{4. "No hay redención sin cruz"}

Damos ahora un paso más y nos preguntamos cómo salva Dios al mundo. Lo que Monseñor Romero enseñó al respecto es quizá lo más duro y difícil de aceptar: el abajamiento y la solidaridad con los pobres conlleva sufrimiento, dolor y muerte, pero no hay otro camino para salvar al mundo. Así nos salvó Dios y así debemos continuar hoy salvando a la humanidad. "No hay rendención fuera de la sangre de Cristo"34:

Hay un camino muy certero que Cristo escogió... Es lo que llama la teología la kénosis, es decir, el deshacerse, el humillarse. Aquel Cristo que, siendo riquísimo y siendo Dios, se hizo pobre para salvar a los pobres y para salvar, desde los pobres, a toda la humanidad. No hay otro camino de salvación (Homilia, 1 de marzo de 1980, VII, p. 282)35.

"No hay redención sin cruz" afirma Monseñor Romero36, lo cual no significa que fuese un predicador del dolor y el sufrimiento. La afirmación simplemente recuerda lo fundamental de la fe: que "el resucitado es el crucificado", esto es, que no hay salvación sin enfrentamiento y lucha contra los poderes del mundo que causan el sufrimiento y la muerte. Este enfrentamiento trae consigo, inevitablemente, dolor y sufrimiento, porque los poderes de este mundo no toleran que nada ni nadie los derribe de sus tronos. Jesús fue crucificado por enfrentarse, en nombre del Dios de la vida, a los ídolos de la muerte, no eludió el conflicto ni, mucho menos, las consecuencias dolorosas de ese conflicto, y al final, murió aplastado por el poder y en un aparente fracaso. Fue a este Jesús crucificado a quien Dios resucitó. Desde entonces no hay otro camino para la salvación que "cargar la cruz".

Cargar la cruz significa, en el lenguaje moderno, solidaridad con los que en este mundo padecen hambre, lloran, sufren, y significa también enfrentamiento profético contra los que en este mundo causan el hambre, el llanto y el sufrimiento. Por ello, no debernos interpretar la predicación de Monseñor Romero

34. Homilia, 15 de julio de 1979, VII, p. 83.

35. Cfr. también Homilía, 16 de septiembre de 1979, VII, pp. 265-266.

36. En la homilfa del 16 de septiembre de 1979. VII, p. 259, se puede hallar una reflexión sobre los falsos mesianismos. Entre ellos, Monseñor Romero señala el "mesianismo sin cruz". 
sobre el sufrimiento como una aceptación ascética y pasiva del mismo, sino como solidaridad con los pobres al igual que Jesús:

El Dios de los pobres ha asumido todo eso y le está enseñando al dolor humano el valor redentor, el valor que tiene para redimir al mundo la pobreza, el sufrimiento, la cruz. No hay redención sin cruz. Pero esto no quiere decir un pasivismo de nuestros pobres, a los que hemos mal adoctrinado cuando les decimos: es voluntad de Dios que tú seas pobre, marginado y no tienes más esperanza. ¡Eso no! Dios no quiere esa injusticia social. Pero una vez que existe y se da, como un tremendo pecado de los opresores - y la violencia más grande está en ellos que privan de felicidad a tanto ser humano y que están matando de hambre a tanto desnutrido- Dios reclama justicia. Pero le está diciendo al pobre, como Cristo al oprimido, cargando con su cruz: salvarás al mundo si le das a tu dolor, no un conformismo que Dios no quiere, sino una inquietud de salvación, si mueres en tu pobreza suspirando por tiempos mejores, haciendo de tu vida una oración, y acuerpando todo aquello que trata de liberar al pueblo de esa siluación (Homilía, 24 de diciembre de 1979, VII, p. 84).

Los pobres de la humanidad son el pueblo crucificado que continúa y completa en la historia lo que falta a la pasión de Cristo. Monseñor Romero nos insta a reconocer en el pueblo oprimido y crucificado la presencia de Jesús crucificado, que continúa su obra redentora:

¡Qué bien se identifica Cristo con el sufrimiento de nuestro pueblo! Asf parecen clamar muchas chozas, muchos tugurios, muchos en las cárceles y en el sulrimiento, muchos hambrientos de justicia y de paz: “ $i$ Dios mlo, Dios mío, por qué me has abandonado?". No nos ha abandonado. Es la hora en que el Hijo de Dios va pasando, con toda su carga de pecados, por la obediencia que Dios le pide para perdonar esos pecados de la humanidad, de donde derivan todas las injusticias, todos los egoísmos (Homilla, 8 de abril de 1979, VI, p. 259).

La teología del pueblo crucificado, la identificación del pueblo con el siervo sufriente de Jahvé y con Cristo crucificado, es una de las más audaces creaciones, pastoral y teológica, de Monseñor y por ello vamos a citar algunos textos más.

Es nuestro pueblo torturado, nuestro pueblo crucificado, escupido, humillado, al que representa Jesucristo, nuestro Señor, para darle a nuestra situación tan diffcil un sentido de redención (Homilia 24 de marzo de 1978, IV p. 103).

Sentimos en el Cristo de los brazos abiertos y crucificados al pueblo crucificado; pero que desde Cristo, un pueblo crucificado y humillado, encuentra su esperanza (Homilia , 19 de marzo de 1978, IV, p. 80) ${ }^{37}$.

37. Cfr. también Homillas, 5 de marzo de 1978, IV, p. 71; 16 de marzo de 1980, VII, p. 339. 


\section{la predicacion COMO PROLONGaCion del PROYeCto}

Como en la reflexión sobre la pobreza, esta identificación de Cristo con el pueblo se traduce y culmina en un compromiso:

Procuremos, hermanos, que Cristo esté en medio de nuestro proceso popular. Procuremos que Cristo no se aleje de nuestra historia. Esto es lo que más me interesa en este momento de la patria: que Cristo sea gloria de Dios, poder de Dios, y que el escándalo de la cruz y el dolor no nos haga huir de Cristo, botar el sufrimiento, sino abrazarlo. Es hora de los proyectos políticos en El Salvador. Proyectos políticos que no valen nada mientras no traten de reflejar el proyecto de Dios. Y la misión del pastor, la misión de la Iglesia, no es entrar en competencias proponiendo un proyecto más, sino, con la autonomía y la libertad de los hijos de Dios y del evangelio, señalar to bueno que puede haber en cada proyecto para animarlo y denunciar lo malo que pueda haber en cualquier proyecto para acabar con él (Homilía, 2 de marzo de 1980, VIII, pp. 291-292).

La solidaridad con los pobres crucificados, sacramento en la historia de Cristo crucificado, no es para quedarse en el sufrimiento y la muerte, sino para liberar al pueblo de esos sufrimientos y muerte, para "bajar de la cruz al pueblo crucificado":

El que convive con el pobre, con el miserable, con el campesino, y lo defiende, y quiere, como Cristo nuestro Señor, predicar la liberación a los pobres, a los oprimidos, a los prisioneros, a los que sufren, ése es Cristo que está en medio de nosotros (Homilia, 23 de marzo de 1978, IV, p. 87).

"El pueblo crucificado tiene así una doble vertiente: es la víctima del pecado del mundo y es también quien aportará la salvación al mundo"38. Que de los empobrecidos viene la salvación del mundo es difícil de aceptar, y es locura que sigue causando el mismo escándalo que cuando los primeros cristianos anunciaron que la salvación viene del que "ustedes mataron en la cruz". La dialéctica cruz-resurrección se traduce en la dialéctica solidaridad-liberación39. Para Monseñor Romero, la figura biblica que mejor expresa esta identificación de Cristo y el pueblo, la unidad entre cruz y resurrección, y la solidaridad para liberar, es la figura del Siervo de Yahvé:

En Cristo encontramos el modelo del liberador, hombre que se identifica con el pueblo, hasta llegar los intérpretes de la Biblia a no saber si el Siervo de Yahvé, que proclama Isaías es el pueblo sufriendo o es Cristo que viene a redimimos. ¡Qué hermoso cuando un liberador se identifica tan profundamente con el pueblo, que su causa es la misma causa del pueblo y del

38. I. Ellacuría, "El pueblo crucificado. Ensayo de soteriología histórica", en Revisia Latinoamericana de Teología 18 (1989) p. 332.

39. Cfr. J. Sobrino, "La pascua de Jesús y la revelación de Dios desde la perspectiva de

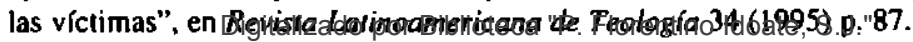


individuo que libera! Cristo es el modelo porque su encarnación también asurne las culpas del pueblo. El, en vez de denunciar y echar en cara a los otros, toma los pecados y debilidades de los hombres y con ellos carga hacia la cruz para pagar a Dios la deuda que nosotros teníamos. En él fuimos perJonados todos los pecadores (Homilía, 21 de octubre de 1979, VII, p. 373).

Ya antes dijimos que no hay salvación fuera de la historia, ahora añadimos que para Monseñor Romero en la historia no hay salvación desde arriba40, desde el poder, cualquiera sea el tipo de poder, sino desde abajo, desde la encarnación en la pobreza y la solidaridad con los pobres, solamente desde allí puede haber verdadera salvación en Cristo.

\section{5. "La salvación es liberación"}

"Esta salvación, que hoy anhelamos tanto, en América Latina toma un nombre muy sugestivo: la liberación"4l. Para Monseñor Romero, "Dios es el gran liberador" 42 y Cristo es "el verdadero líder de la liberación"43. "La libertad es la que nos hace iguales a Dios" 44 . Y como la salvación se realiza en la historia, necesita de mediaciones históricas para realizarse. Estas mediaciones son los procesos de liberación.

Una de las mayores insistencias de las homilías de Monseñor Romero es hacer ver, por una parte, que estos procesos temporales de salvación necesitan incorporarse al proyecto salvílico de Dios para que sean verdaderos procesos de liberación, y, por la otra, que el proyecto salvífico de Dios comienza por la liberación de las esclavitudes de la tierra:

Esa redención de Cristo no solamente es una redención que la esperamos después de la muerte, es una redención que ya se opera en esta vida. Y la palabra que a muchos molesta, la liberación, es una realidad de la redención de Cristo; que liberación quiere decir la redención de los hombres, no solamente después de la muerte para decirles: "confórmense mientras viven". No, una liberación que es una redención que ya comienza en esta tierra, liberación que quiere decir que no exista en el mundo la explotación del hombre por el hombre. Liberación quiere decir redención que quiere liberar al hombre de tantas esclavitudes. Esclavitud es el analfabetismo. Esclavitud es el hambre, por no tener con qué comprar comida. Esclavitud es carencia de techo, no tener donde vivir. Esclavitud, miseria, todo eso va junto (Homilia, 25 de noviembre de 1977, I-II, p. 342).

40. Cfr. Homilia, 12 de febrero de 1978, IV, p. 17.

41. Homilia, 26 de marzo de 1978, IV. p. 118.

42. Homilia, 18 de marzo de 1979, VI, p. 210.

43. Homilía, 13 de enero de 1980, VIII, p. 146.

44. Homilia, 24 de diciembre de 1978, VI, p. 60. 
Como es conocido, la liberación implica dos momentos. Uno es negativo: liberarse del pecado, "arrancar de la historia los pecados, arrancar de la política los pecados, arrancar los pecados de la economía, arrancar los pecados allí donde estén"45. El otro es positivo: liberarse para instaurar el reino de Dios. Con esto, Monseñor Romero nos enseña que la liberación es luchar en contra de algo, de ahí su carácter conflictivo, y es luchar a favor de algo, y de ahí su carácter esperanzador:

Esto es el aspecto negativo de nuestro mensaje: el pecado. Es una guerra a muerte contra el pecado. Ese pecado tiene sus raíces en el demonio y tiene sus frutos. Los frutos son la enfermedad, la miseria, el analfabetismo, la desnutrición, la injusticia social, todo eso que vemos que brota, es lo que echa de fruto este tronco que es el pecado enraizado en el infierno que es el diablo. La lucha del pueblo profético es, pues, contra el pecado, contra el diablo y contra las consecuencias de todo eso, las liberaciones también de las esclavitudes de la tierra. Por eso, querer hablar únicamente de confesarse para no tener pecados uno, pero luego no luchar también contra la injusticia del ambiente, no es ser verdadero pueblo de Dios. Es necesario que, junto con el esfuerzo de no tener yo pecados personales, trabaje también para arrancar los pecados sociales y de rafz, contra el poder del infierno y del demonio... "El reino de Dios ha llegado a vosotros". Esta es la parte positiva. No se trata sólo de arrancar el pecado y sus consecuencias, los egoísmos de la tierra. Serla una religión muy negativa si sólo hablara asl. Pero lo hermoso es que ese vacío que va a dejar el pecado y el infierno y las esclavitudes de la tierra, va a ser llenado por el reino de Dios (Homilia, 15 de julio de 1979, VII, p. 82) 46 .

Siguiendo al Vaticano II, Medellín y Puebla, para Monseñor Romero la liberación es integral. Hombre y sociedad es lo que se debe salvar, y esta liberación exige derrocar a los ídolos de la muerte que estorban al reino de Dios:

La liberación que Cristo ha trafdo es del hombre integral. Es todo el hombre el que urge salvar: alma y cuerpo, individuo y sociedad. Es el reino de Dios que hay que establecer ya en esta tierra. Es ese reino de Dios que se siente estorbado, maniatado por tantos abusos de la idolatría del dinero y del poder y es necesario derrocar esos falsos ídolos (lbid., VI. p. 101).

¡Ay de los poderosos cuando no tienen en cuenta el poder de Dios, el único poderoso! Cuando se trata de torturar, de matar, de masacrar para que se subyuguen los hombres al poder, iqué tremenda idolatría! que les están ofreciendo al clios poder, al dios dinero, tantas víctimas, tanta sangre, que Dios, el verdadero Dios, el autor de la vida de los hombres, se lo va a cobrar bien caro a esos

45. Homilía, 15 de enero de 1978, III, p. 154.

46. Cfr. también Homilia, 14 de octubre de 1979, VII, p. 346. 
idólatras del poder (Homilia, 24 de febrero de 1980, VW, p. 263).

Así como la liberación es integral, así también el pecado lo abarca todo. El pecado está enraizado en el "corazón humano" y se adhiere a la sociedad en una "estructura de pecado". Es lo que en el lenguaje de Juan se llama "pecado del mundo". La liberación comienza "arrancando" el pecado del mundo:

Así es el pecado, es muerte. Por eso, donde quiera que hay muerte hay pecado. La muerte es la señal evidente de que el pecado reina. Espanta pensar que en la patria hay tantos muertos y que los caminos sagrados de nuestro suelo se empapan cada vez más de sangre humana. El pecado reina en El Salvador y los liberadores de El Salvador tienen que comenzar por allí: cómo arrancar el pecado de nuestro suelo. Esto es el proyecto de Dios, de alll parte el proyecto de Dios. Y todo proyecto político que no tenga en cuenta el pecado, la injusticia, el querer mantener la injusticia social, es querer mantener entronizado el pecado y echar aparte a Dios. Sin Dios no puede haber liberación y donde hay pecado no puede estar Dios. Los proyectos que solamente se montan para mantener privilegios escandalosos, no pueden ser de Dios (Homilía, 2 de marzo de 1980, VIII, pp. 292-293).

Monseñor constata y denuncia la "estructura de pecado", y por ello afirma también que la liberación exige construir una "estructura de salvación":

La verdadera vocación de los salvadoreños está en que lleguemos un día a constituir ese reino de Dios, no sólo bautizados de nombre sino efectivamente cristianos, comprometidos a hacer de nuestros hogares, de nuestras haciendas, de nuestras fincas, de nuestros caminos, de nuestras leyes, toda una estructura de salvación (Homilía , 11 de diciembre de 1977, III, p. 58).

Esta "estructura de salvación" hay que construirla a diversos niveles, y por ello exige un compromiso histórico, social y aun político:

El proyecto de Dios es el proyecto del reino de Dios. Y todos los proyectos de progreso en el mundo no se deben confundir con el proyecto del reino de Dios; pero sí deben de hacerse cada vez más como un reflejo del reino de Dios. Y nuestra patria resolverá su problema en la medida en que trate de reflejar aqui, entre los salvadoreños, entre los ricos y los pobres, la justicia del reino de Dios, el amor del reino de Dios. Así como también está estorbando al verdadero progreso material de El Salvador el que nos opongamos al proyecto del reino de Dios. Y se opone al proyecto del reino de Dios el que unos pocos lo tengan todo y una mayoría no tenga nada. Hermanos, es hora de decisiones muy graves en nuestra patria, y los hombres tienen que optar por un trabajo también en el campo y en el progreso humano, en la política. Pero tienen que .llevar, si son verdaderamente cristianos, muy grabada en su mirada, en su corazón, en su mente y en su actividad, el proyecto del reino de Dios (Homilía, 10 dẹ febrero de 1980, VIII, p. 216). 
Sin embargo, el aporte de la Iglesia y de los cristianos no consiste en ofrecer un sistema político propio, sino en dar "un sentido trascendente" 47 a los proyeclos que van construyendo los seres humanos:

La Iglesia no predica ningún sistema concreto. La Iglesia no ofrece ningún método, pero la Iglesia ofrece los principios de la verdadera libertad: creer en el Dios liberador. Y de allí surgirá para cada hombre su opción libre. Todo hombre es libre para optar por el camino político por el cual quiera ayudar a la patria, tiene derecho a organizar con otros que piensen como él los caminos de la verdadera liberación (Homilia, 9 de julio de 1978, V, p. 58).

Se deben, pues, evitar dos reduccionismos según Monseñor Romero: una liberación sin Dios y una liberación sin compromiso con la historia. El servicio de la Iglesia es, precisamente, mantener el equilibrio entre la fe y la política, entre los proyectos históricos de liberación y el proyecto salvífico de Dios:

Que nos quede bien claro, hermanos, que lo que Cristo quiere, al darnos de comer, al estar con nosotros, es, sí, preocuparse. ¿Cómo no va a llorar Cristo con la madre que llora la desaparición de su hijo? ¿Cómo no va a sufrir Cristo con el pobre que murió entre toruras? ¿Cómo no va a reprochar Cristo el crimen de los guardias y de ORDEN que se llevan preso en forma burlesca al hijo que deja desamparada a una familia? ¡Claro que eso no quedará sin pagar! Por eso, precisamente, Cristo invoca la justicia eterna. No es en esta tierra, donde, a pesar de escribir al presidente de la Corte Suprema de Justicia, las cosas seguirán lo mismo. El no es Cristo, pero hay un Cristo encima de él que le pedirá cuentas a él y le pedirá cuentas a todos los que son cómplices de esta situación injusta de El Salvador. Por eso Cristo invoca una situación más allá de la historia. Y yo quisiera, queridos hermanos que sufren, hogares desamparados, encarcelados, torturados, prisioneros, que no se desesperen. Cristo está con nosotros. El Divino Salvador del Mundo está como estaba en medio de la muchedumbre que tenía hambre. El sabe la solución y la dará... Yo quisiera decirles... este mensaje transcendente e inmanente. Transcedente, es decir, que va más allá de la realidad presente. Inmanente quiere decir que está en la realidad presente. Eso es Cristo, aquí y ahora, pero también más allá y en la eternidad. Es peligroso, entonces, perder este equilibrio de inmanencia y trascendencia... Es lo que se llama un reduccionismo temporal; así como es malo también un reduccionismo espiritual (Homilia, 29 de julio de 1979, VII, pp. 126-127).

Las últimas palabras de Monseñor Romero en la catedral, verdadero testamento, hablan precisamente de liberación. Son el mejor resumen de lo que hemos expuesto y con ellas terninamos este apartado:

47. Homilia, 26 de febrero de 1978. IV, г 47 
La Iglesia predica su liberación tal como la hemos estudiado hoy en la Sagrada Biblia, una liberación que tiene, por encima de todo, el respeto a la dignidad de la persona, la salvación del bien común del pueblo y la trascendencia que mira ante todo a Dios y sólo de Dios deriva su esperanza y su fuerza (Homilia, 23 de marzo de 1980, VIII, p. 382).

Las mejores palabras que se hayan podido decir de Monseñor Romero son de Ignacio Ellacuría48. Dijo que Monseñor Romero es "un enviado de Dios para salvar a su pueblo"49. Y Monseñor Romero lo fue no sólo hablando de la salvación, tal como lo hemos expuesto hasta ahora, sino que toda su vida y su muerte son el mejor testimonio de lo que él predicó. La vida y muerte de Monseñor Romero son su mejor "homilfa", el mejor ejemplo de lo que significa ser liberador del pueblo y encarnación en la historia del designio salvador de Dios.

Monseñor Romero fue, efeclivamente, un "enviado de Dios para salvar al pueblo" porque trabajo incansablemente para que la "salvación fuese operativa y, para ello, que fuese asumida gozosamente, esperanzadamente por los destinatarios primeros y principales de esa palabra de salvación. Y llevó esa convicción hasta sus últimas consecuencias cuando vio, en el pueblo sin voz, a la voz misma de Dios, en el pueblo crucificado, al Dios Salvador, en las luchas de liberación, el camino para la llegada de la nueva tierra y del nuevo cielo"so.

\section{La prolongación del misterio salvífico de Cristo}

Hasta ahora hemos expuesto la estructura de las homilías de Monseñor Romero, y hemos argurnentado que esto no obedece a razones puramente metodológicas, sino a razones teológicas. Si Dios salva en la historia, si Cristo está presente en los pobres y con ellos sigue salvando al mundo, si la Iglesia de los

48. Monseñor Romero e Ignacio Ellacuria tienen en común el martirio por la misma causa y por el mismo pueblo. $Y$ entonces, no nos debe extrañar que también coincidan en su pensamiento. Si hemos dicho que la salvación fue el tema central de las homillas de Monseñor Romero, la salvación es también el tema central de los escritos teológicos de Ignacio Ellacuría. Lo que uno dice en lenguaje pastoral y profético, el otro to expresa y sistematiza en lenguaje teológico. Baste leer la homilías de Monseñor Romero y los escritos de Ignacio Ellacuría para percatarse a simple vista que ambos, en lenguajes diferentes, dicen fundamentalmente lo mismo. Con esto no estoy insinuando que el teólogo influyó en el pastor; de hecho, se acusó a la UCA, de la que el era rector, de manipular a Monseñor Romero. El mismo Ellacuría zanjó la cuestión al afirmar que estaba claro quién era el profeta y quién era el seguidor, y profela, por supuesto, era Monseñor Romero.

49. 1. Ellacurfa, "Monseñor Romero, un enviado de Dios para salvar al pueblo", en $R e$ vista Latinoamericana de Teología 19 (1990) pp. 5-10.

50. Ibid., p. 8. 
pobres es el sacramento universal de salvación, si los cristianos deben quitar el pecado del mundo y hacer presente el reino de Dios, entonces, es necesario ver y juzgar la realidad actual y actuar sobre ella, es necesario descubrir "la mano de Dios en la coyunturas históricas", es necesario animar a la Iglesia local a cumplir su misión, es necesario juzgar los proyectos políticos temporales para que sean "reflejo" del reinado de Dios.

Por esa razón teológica, las homillas deben tener una segunda parte de encarnación de la doctrina en la realidad de los oyentes (hechos de la semana), pues la predicación es prolongación del misterio salvílico de Cristo. Así, en la primera parte de sus homilías Monseñor Romero expone, guiado por la palabra de Dios y la doctrina del magisterio eclesial, el plan de salvación de Dios, y en la segunda parte hace que ese plan de salvación se prolongue a la realidad actual de los oyentes.

Este esquema homilético no fue as desde el principio. Si leemos las primeras homilías comprobamos que el orden de exposición es el inverso. Por ejernplo, en una homilía del primer año de su ministerio pastoral en la arquidiócesis, la del 24 de julio de 1997, hallamos esta estruclura formals!: Introducción, comentario de la vida eclesial y de la realidad nacional, explicación de la palabra de Dios, conclusión. Es en la homilla del 14 de mayo de 1978, fiesta de pentecostés, donde se observa por primera vez el esquema definitivo de sus homilías: introducción, explicación de la palabra de Dios, aplicación de la palabra de Dios a la realidad eclesial y nacional, conclusión. Esto ocurrí sin que, en el texto de la homilfa, Monseñor Romero adujese ninguna razón que justificase este cambios2.

Pero volvamos a la reflexión sobre la realidad que aparece en sus homilías. Monseñor Romero calificó a la predicación que no se arriesga y encarna en la realidad histórica como una predicación espiritualista53, y a veces llegó a no considerarla como verdadera predicación cristiana ${ }^{54}$. Simultáneamente, sin embargo, hizo reiterados llamados para que los oyentes no mostrasen interés sólo en la aplicación de la palabra de Dios a la realidad, sino que se abriesen, creyentemente, a la totalidad del mensajes5. Quizás pueda estar aquí la razón por la que Monseñor Romero invirtió el orden de la exposición, pues, cuando algo grave sucedía en el pals, todo el mundo esperaba con expeclación que llegase el domingo para escuchar qué diría Monseñor sobre ese hecho. Es probable, pues, que Monseñor Romero comprobara que si comenzaba hablando y enjuiciando la realidad, decreciera la atención hacia la exposición bíblica y doctrinal posterior.

51. Cfr. Homilia, 24 de julio de 1977, I-II, pp. 136-144.

52. Cfr. Homilía, 14 de mayo de 1978, IV, pp. 233-248.

53. Cfr. Homilia, 16 de julio de 1978, V, p. 71.

54. Cfr. Homilia, 2 de abril de 1978, IV, pp. 127-128.

55. Cfr. Homilia 16 de marzo de 1980, VIII, p. 331. 
Por el contrario, si comenzaba por esta exposición bíblica y doctrinal, la tensión y la atención se mantenían hasta el final de la homilía. Sea lo que fuere, no es muy importante saber la razón del cambio en el orden de exposición de las homilías de Monseñor Romero, ya que este cambio no altera en nada la intuición fundamental: la palabra de Dios y la realidad histórica deben estar en relación y tensión continua en el transcurso de la homilía.

Hechas estas aclaraciones, vamos a analizar ahora cómo Monseñor Romero lleva a cabo lo que hemos llamado la prolongación del misterio salvífico. Vamos a estudiar, pues, cómo es la segunda parte de sus homilías56, que liene, a su vez, dos partes. La primera es la reflexión sobre la prolongación del misterio salvííco en la realidad eclesial: (a) en la Iglesia local, y (b) en Ia Iglesia universal. La segunda es la reflexión sobre la prolongación de ese misterio en la realidad nacional: (a) denuncias, (b) análisis y juicios de la realidad política, económica, militar y social del pals, (c) voz del pueblo organizado y de las fuerzas sociales, y (d) llamamiento a la conversión.

Monseñor Romero comienza la segunda parte de sus homilías con una crónica de lo que ha sido la actividad pastoral de la semana, de tal manera que hoy podríamos reconstruir la historia del quehacer pastoral de la arquidiocesis reuniendo estas crónicas, a las que él también llama "noticiero". Su intención es hacer de la Iglesia, una Iglesia presente en los problemas del país, pero fiel a su propia identidad eclesial. En estas crónicas, está reflejada la vida e historia de la arquidiócesis de San Salvador, sus virtudes y sus pecados, sus logros y sus dificultades.

En primer lugar, Monseñor Romero hace un minucioso recorrido de toda la actividad pastoral que él y toda la arquidiócesis han realizado durante la semana, y comenta algunos hechos que le parecen más importantes. Veamos algunos ejemplos.

A veces, felicita y anima a los agentes de pastoral:

En un bonito cantón del volcán, jurisdicción de Quezaltepeque, Volcán San Juan, Los Planes, hay un ejemplo de trabajo de los cristianos en comunidad de base. Dos novios, Carlos y Rosi, tomaron con empeño ir a hacer allá una comunidad y ya tienen muchos meses trabajando, y se ve que va floreciendo la comunidad donde yo tuve la dicha de celebrar la primera comunion y presentar hoy este ejemplo de lo que puede hacer el apóstol seglar (Homilia, 30 de diciembre de 1979,VIII, p. 100).

Otro ejemplo. Cuando no ha podido cumplir algún compromiso pastoral, pide disculpas y reconoce y valora las cualidades y habilidades de los campesinos:

En San Antonio Los Ranchos, la tradicional fiesta del maíz. Por tercera vez

56. Cfr. M. Cavada Diez, op. cis., pp. 6-8.

Digitalizado por Biblioteca "P. Florentino Idoate, S.J."

Universidad Centroamericana José Simeón Cañas 


\section{la predicacion COMO pRolongacion del proyecto}

les he fallado, no pude ir, pero me sabrán perdonar porque comprendieron mis razones. $\mathrm{Y}$ generosos como son, me mandaron un bonito sombrero hecho de tuzas y adomado con pelo de maíz. Quien lo ve a primera vista, parece como que fuera un bonito sombrero de junco. ¡Cómo han logrado manejar allá lo que se bota del maíz, tuzas, pelo de maíz, olotes! Todo es aprovechado en un arte que vale la pena acuerpar. Yo los felicito, queridos habitantes de San Antonio Los Ranchos, por ese esfuerzo de superar la situación de pobreza y presentar un afán (Homilía, 30 de diciembre de 1979, VIII, p. 100).

Otras veces lee las sencillas cartas del pueblo y agradece su apoyo:

En lo personal he sentido mucho agradecimiento por una bonita carta de las vendedoras del cine México. Mandaron una aportación económica según sus pobrezas y dicen: "Reciba nuestras felicitaciones y que Dios siempre lo ilumine para seguir adelante en su empeño y amor en esta lucha por el pueblo salvadoreño. Hemos hecho esta pequeña contribución que se la enviamos para lo que usted crea más conveniente". Yo les agradezco por un gesto tan simpático (Homilia, 13 de enero de 1980, VIH, pp. 15I-152).

Comenta sus visitas pastorales durante la semana:

Participé el domingo pasado en la convivencia de laicos de la vicaría de Cuscatlán que se reunieron en San Pedro Perulapán. Muy animados de una promoción laical que nuestra diócesis está llevando a todas partes. El dla del Señor de Esquipulas celebré también en Aguilares una fiesta patronal muy animada, ya que allá hay muy bonitas comunidades eclesiales de base, que cuando se reúnen así en las grandes concentraciones parroquiales, le dan un sentido muy profundo a la oración comunitaria (Homilía, 20 de enero de 1980, VШ, p. 172).

Se solidariza con los sacerdotes y comunidades perseguidas - lo cual ocurria con frecuencia- y anima a continuar en el trabajo pastoral:

Los padres belgas en la comunidad de Zacamil recibieron amenazas el domingo recién pasado. Somos solidarios con ellos y esperamos que no se abuse de sus vidas y que sepan seguir trabajando por nuestra comunidad, por nuestra Iglesia (Homilía, 9 de marzo de 1980, VIU, p. 320).

En la parroguia Miramonte hubo un intento de bloquear y de intimidar una procesión de antorchas que la parroquia había organizado en el segundo aniversario de la muerte del padre Navarro. Queridos hermanos, yo creo que todo esto son notas que con razón se pueden llamar persecución. Esto no es un estímulo para la Iglesia, sino un estorbo a su urabajo (Homilía, 20 de mayo de 1979, VI, p. 355).

Se hace eco de lo que las comunidades cristianas piensan y comunica los Digitalizado por Biblioteca "P. Florentino Idoate, S.J.

Universidad Centroamericana José Simeón Cañas 
resultados de reuniones pastorales:

Desde el jueves al sábado se tuvo un estudio de pastoral sobre comunidades eclesiales de base, en que agentes de pastoral han aprendido mucho para poner en práctica esta línea que nuestra arquidiócesis tanto estima: hacer comunidades eclesiales de base (Homilia, 20 de enero de 1980, VIII, p. 171).

Comparte y corrige problemas pastorales:

Quiero lamentar los fanatismos de tradiciones opuestas a la pastoral de nuestra diócesis. Tengan mucho cuidado comunidades cristianas. Hay gente empeñada en mantener tradiciones que no son ya legítimas tradiciones porque se oponen a una Iglesia que quiere ser viva expresión de la redención de Cristo. También quiero lamentar los abusos de aquellas innovaciones que son imprudentes y no tienen en cuenta los sentimientos legítimos de nuestro pueblo (Homilía, 14 de abril de 1979, VI, pp. 299-300).

Ustedes saben que, ante la situación, he organizado un comité de solidaridad. Por una generosa iniciativa de una señora se hizo el llamamiento a todas las organizaciones de que nos acordamos. Llegaron muchos, pero muchos solamente mandaron el recado: "No podemos, porque no podemos tomar partido". Otro: "porque no nos podemos meter en política". ¡Qué lástima, hermanos, que seamos tan indiferentes bajo el pretexto de no meterse en política! Se quedan con los brazos cruzados y hacen el bien únicamente cuando hacer el bien es fácil o es glorioso, trae prestigio. Servir es sacrificarse (Homilía, 2 de abril de 1978, IV, p. 133).

En algunas ocasiones anuncia lo que sucede en la Iglesia universal y da a conocer los documentos y mensajes del magisterio latinoamericano y universal57, de tal manera que este momento de la homilía es como un noticiero, como así lo llamaba él58.

Se puede pensar que el noticiero no es parte fundamental de la homilía. Algunos piensan que los avisos y noticias de la vida comunitaria deben hacerse brevemente al final de la eucaristía, antes de la bendición final, pues de lo contrario se interrumpe el ritmo litúrgico y se distrae la atención de la finalidad primordial de la eucaristía. Monseñor Romero no pensó asf. Los hechos pastorales y las noticias eclesiales son parte esencial de la homilía.

"Hacer nuestra Iglesia59" era la primera finalidad que Monseñor Romero señalaba para sus homillas, y mal se puede lograr este objetivo si los hechos pastorales, las realizaciones y los problemas de la comunidad cristiana son omitidos o relegados al final de la misa, reducidos a la mínima expresión. Monseñor

57. Cfr. Homilía, 25 de marzo de 1979, VII, pp. 231-233.

58. Cfr. Homilia, 6 de noviembre de 1977, I-II, p. 305.

59. Homilía, 14 de octubre de 1979, VII, p. 348. 
Romero se tomó en serio esta finalidad e hizo ver que el noticiero no es sólo para informar, sino para compartir, para hacer Iglesia60. Toda la comunidad arquidiocesana se reconocla en las homilfas de Monseñor Romero. Es indudable que estas crónicas pastorales contribuyeron en gran medida a dar unidad e identidad a la arquidiócesis, sin ellas no hubiera sido tan notorio el impulso pastoral que tuvo la arquidiócesis.

Después de revisar la vida de la Iglesia, Monseñor Romero fija su mirada en la realidad del país. Entonces eleva, en nombre de Dios y del pueblo pobre, su voz profética de denuncia. Era el momento más esperado de la homilía. Denuncia sobre todo la represión contra el pueblo, porque nada hay más importante que la vida. Para Monseñor Romero, todas las víctimas de la represión tienen un nombre, las nombra una a una, semana a semana, se solidariza con los familiares. Y también los responsables de la injusticia y de la violencia tienen nombre, los pone al descubierto y los llama a conversión.

En sus denuncias Monseñor quiere llegar a la raíz, y por eso, muchas veces van acompañadas de análisis de la realidad socio-política con el fin de señalar las causas del mal y de desenmascarar a sus responsables. Nada ni nadie escapa al juicio profético de Monseñor Romero, que muchas veces va acoinpañado de severas advertencias. No es ahora nuestro propósito hacer un estudio de las denuncias de Monseñor Romero61, pero ofreceremos, a modo de ejemplo, algunas denuncias para darnos una idea de cómo son sus homilías.

Ante todo, Monseñor Romero pone al descubierto la tremenda realidad de represión y muerte que sufre el pueblo. Muchas de las violaciones de los derechos humanos y de los asesinatos hubieran quedado en el anonimato si él no los hubiera dado a conocer. Fue la voz de los pobres:

Parecen expresarse -todos estos atropellos- en las cartas que llegan frecuentemente al arzobispado, como la de una madre que dice: "Soy una esposa y una madre angustiada porque desde el 29 de mayo pasado la Guardia se llevó preso a mi esposo, Mercedes, y a mi hijo José Mario, juntamente con mi hermano Pedro Juan. Cuando los apresaron estaban sembrando arroz cerca de la casa. Los hemos buscado por muchas partes y no los hemos encontrado. Usted se imagina la angustia que tengo con mis hijos y le ruego que, por favor, en su predicación del domingo pregunte a las autoridades por estos desaparecidos. Se lo pido de lodo corazón". Esta es la voz que no se oye y a la que nosotros tenemos que hacer ofr. No serfa verdadero evangelio

60. Cfr. Homilia, 6 de noviembre de 1977, I-II, p. 305.

61. Una buena sistematización y selección de las denuncias de Monseñor Romero se puede encontrar en el libro de Jon Sobrino, Monseñor Romero, verdadero profela (Bilbao, 1982), sobre todo en las páginas 45-78. 
si fuéramos indiferentes a tantas angustias, sobre todo cuando estas angustias tratan de apañarse con promesas y noticias que no dicen la realidad sino que esconden siempre eso que tanto tememos (Homilia, 19 de agosto de 1979, VII, p. 189).

También en este momento de la homilía Monseñor Romero enjuiciaba los hechos más importantes de la semana ya sea de carácter político, económico o militar. Monseñor Romero insistió en reiteradas ocasiones en que su criterio de juicio no era político ni sociológico, sino teológico e histórico. El criterio para juzgar la realidad eran los pobres:

Según les vaya a ellos, al pueblo pobre, la Iglesia irá apoyando desde su especifidad de Iglesia, uno u otro proyecto político. O sea que la Iglesia asI es como mira este momento de la homilía: apoyar aquello que beneficie al pobre, así como también denunciar todo aquello que sea un mal para el pueblo. Con este criterio vamos a juzgar algunos hechos de esta semana (Homilia, 17 de febrero de 1980, VIII, p. 246)62.

En sus juicios de la realidad, Monseñor Romero era más analítico que descriptivo. En todas las coyunturas económicas, sociales o políticas buscaba las causas del mal para proponer cambios estructurales profundos:

En primer lugar denunciar más violencia. Cabalmente estamos diciendo que la raíz no se toca, que está fértil, que tiene que seguir produciendo malestar una injusticia social a base de una aberración de la propiedad y de una absolulización de la riqueza, que para colmo se trata de defender con la represión. Allí está la causa de todo: injusticia social y represión, que no es otra cosa que contradecir la doctrina que hoy hemos leído en la misma Biblia (Homilia, 30 de septiembre de 1979, VII, pp. 310-311).

Aquí quiero empalmar yo, con la palabra divina del Señor, la denuncia que la Iglesia tiene que hacer a todo eso podrido que sale del corazón de muchos salvadoreños. Por ejemplo, esta semana ha habido muchas declaraciones de fuentes gubernamentales informando ante la asamblea legislativa. Se reconoce ciertamente que hay en el país graves problemas de orden político, social y económico... pero no señalan las causas... La Iglesia también señala esas diferencias pero dice que la causa principal de esos problemas es la injusticia social... La verdadera expresión del amor es compartir... Fljense si no son dignos de malos corazones estos datos estadísticos: el 60 por ciento de la población urbana, en las ciudades, liene un ingreso personal entre 42 y 140 colones mensuales. Lo cual quiere decir que un millón y medio, casi, de habitantes en las ciudades cuenta para vivir apenas con 1.40 ó a lo más 4.60 colones. $¿$ Creen ustedes que una persona puede vivir diariamente con 1 co-

62. Cfr. también Homilía, 20 de agosto de 1978, V, p. 134. 
lón y 40 centavos? ¡Esta es la situación! (Homilía, 2 de septiembre de 1979, VII, p. 220).

Asimismo, dadas las graves restricciones a la libertad de expresión, Monseñor Romero se hace voz de las diferentes fuerzas sociales, especialmente de las organizaciones campesinas y de los sindicatos. No es raro encontrar en este momento de la homilía extensas lecturas de comunicados de asociaciones gremiales, de universidades o de organizaciones populares63. Y Monseñor Romero muestra especial interés por aquellos comunicados que ofrecen soluciones a los graves conflictos del país.

Monseñor siempre une a la denuncia el llamamiento a la conversión y a transformaciones esiructurales de la sociedad salvadoreña. Estos llamamientos son una constante en sus últimas homillas64, precisamente cuando la situación política se habla tornado más crítica y grave. Monseñor Romero hace llamamientos a la oligarquía, al gobiemo, a la Fuerza Armada y a los cuerpos de seguridad, al gobierno de Estados Unidos, a las organizaciones populares, a las organizaciones político-militares, al pueblo no organizado, a los cristianos y a la misma Iglesia arquidiocesana. A cada sector dio una palabra oportuna y exigente. De todos estos llamamientos, el más conocido es el que dirigió en su última homilía al ejército y a los cuerpos de seguridad. Selecciono ahora el que considero más bello y también tremendo. Bello, porque en él Monseñor Romero se presenta como lo que realmente fue, el "amigo de este pueblo". Tremendo porque hace un dura advertencia a los ricos:

Un llamamiento a la oligarquía. Les repito lo que dije la otra vez: no me consideren juez ni enemigo, soy simplemente el pastor, el hermano, el amigo de este pueblo, que sabe de sus sufrimientos, de sus hambres, de sus angustias. Y en nombre de esas voces, yo levanto mi voz para decir: no idolatren las riquezas, no las salven de manera que dejen morir de hambre a los demás. Hay que compartir para ser felices. El cardenal Lorscheider me dijo una comparación muy pintoresca: "hay que saber quilarse los anillos para que no les quiten los dedos". Creo que es una expresión bien inteligible. El que no quiere soltar los anillos, se expone a que le corten la mano y al que no quiera dar por amor y por justicia social, se expone a que se lo arrebaten por la violencia (Homilía, 6 de enero de 1980, VIII, 134).

63. Cfr. Homilias, 21 de oclubre de 1979, VII, p. 368; 4 de noviembre de 1979, VII, pp. 408-409.

64. Cfr. Homilias, 16 de diciembre de 1979, VIII, pp. 55-58; 23 de diciembre de 1979. VIII, pp. 78-79; 6 de enero de 1980, VIII, pp. 13!-134; 13 de enero de 1980, VIII, pp. 203-204; 17 de febrero de 1980, VIII, pp. 247-253; 24 de febrero de 1980, VIII, pp. 274-277; 16 de marzo de 1980, VIII. pp. 354-356; 23 de marzo de 1980, VIII. p. 382. 
Este breve recorrido por sus homilías nos muestra cómo Monseñor Romero prolongaba el plan de salvación de Dios en la realidad histórica que le tocó vivir. Y esto es lo que falta en la mayoría de las homilías en la Iglesia, con lo cual se comete el grave error de vaciar la palabra de Dios de su fuerza liberadora:

Tenemos que mirar desde esta perspectiva el misterio de nuestra salvación porque la historia de cada pueblo, de cada familia, es como el instrumento de Dios para salvar a ese hombre, a ese pueblo, a esa familia. Por eso, puede parecer muchas veces que la predicación toca cosas muy peligrosas y que sea más fácil callar, pero entonces no cumpliría la palabra evangélica su misión de iluminar, en el misterio de Cristo, la realidad del pueblo (Homilía, I de julio de 1979, VII, 40).

\section{La preparación de la homilía}

Homilías tan densas en su contenido teológico y tan audaces en su mensaje profético no son producto de la casualidad ni de la improvisación. Monseñor Romero preparaba cuidadosamente sus homilías, y esto también nos deja un enseñanza magistral.

Como es reconocido por muchos, el mal de la predicación en nuestra Iglesia comienza con su escasa o nula preparación. Desgraciadamente, la mayorfa de los predicadores, absorbidos por su actividad pastoral o paralizados por la pereza intelectual, apenas dedican unos minutos a meditar y planificar su predicación dominical. A lo sumo, limitan esta preparación a leer alguna "hoja dominical" con explicaciones exegéticas y recomendaciones pastorales. Por eso, considero importante incluir en este trabajo una breve reflexión sobre el espíritu y el procedimiento con que Monseñor Romero preparaba sus predicaciones dominicales.

\subsection{Búsqueda sincera de la verdad}

"Ayúdenme para que siempre pueda llevar esta palabra de Dios"65. Son palabras que Monseñor Romero dice al comienzo de su labor como arzobispo de San Salvador. Monseñor Romero pide ayuda y se deja ayudar. Y esto es así porque no se cree el único poseedor de la verdad y añade que debemos "buscar entre todos la verdad"66. Este convencimiento se traduce en una permanente disposición al diálogo. Monseñor Romero repetidamente pide que se dialogue con él cuando hay disparidad de criterios o diferentes visiones sobre la realidad:

65. Homilía, 15 de mayo de 1977, I-Il, p. 52.

66. Homilia, 9 de abril de 1978, IV. p. 145. 
El espiritu de Dios pone de veras, lo que dice el evangelio de hoy, las palabras que se deben decir. Es natural que la interferencia humana, mis defectos, mis errores, mis limitaciones puedan interferir con pensamientos falsos, palabras tal vez disonantes. Pero entonces, hermanos, háganme la caridad de corregirme, diganme lo que no les parece y dialoguémoslo, como lo he hecho muchas veces, y que ojalá pueda ser fiel al pensamiento que tengo que transmitir, el de nuestro Señor (Homilia, 13 de noviembre de 1977, I-I, Pp. 322-323).

Esta actitud la mantuvo hasta el final. En enero de 1980 pide que se lea y analice su homilía publicada en Orientación y que se le envíen sugerencias sobre la misma67. Y desde esta perspectiva, podemos abordar un tema, debatido desde hace unos años sobre la conveniencia o no de las homilías dialogadas68. No es que el tema nos ocupe ahora, pero creemos que Monseñor Romero arroja luz sobre cómo enfocarlo. Y es que, en realidad, la discusión no versa sobre si procede o no entablar un diálogo con los fieles durante la homilía misma. De sobra está decir que cuando se trata de una multitud ese diálogo es imposible. Se trata más bien de descubrir la actitud adecuada del predicador: éste debe estar en actitud permanente de diálogo con su pueblo y con su realidad histórica.

Y esto es lo que nos enseño Monseñor Romero. Sus homilías tocan el corazón del pueblo, porque son expresión de sus necesidades y pensamientos, son su voz. Sería inútil discutir sobre la conveniencia de un diálogo con la asamblea en el momento de la homillá, si la predicación está alejada de la realidad y no es voz del pueblo, si es una predicación desencarnada y desarraigada, si no hay una actitud y una práctica de permanente diálogo y búsqueda sincera de la verdad.

Lo que estamos diciendo lo resume Monseñor Romero en pocas palabras: todo el que predica tiene que ser antes un discípulo que oye69. Por supuesto, esta actitud y esta práctica de diálogo necesita formas concretas, un cauce para ser real y para que no se quede en meras intenciones. Estas formas pueden ser diversas. Los aplausos espontáneos del pueblo son una forma de entablar diálogo. La conversación informal en el momento litúrgico de la homilía puede ser otra forma de diálogo posible y fructífero en asambleas pequeñas. Pero lo esencial es que haya dialogo real.

Monseñor Romero dialoga con su pueblo en las visitas pastorales, en las audiencias en el arzobispado a las que, como se sabe, concurría una interminable procesión de gente pobre para exponerle sus problemas, en las visitas que recibía en su casa, el hospitalito. Monseñor Romero, porque ha "visto y ofdo",

67. Cfr. Homilia, 13 de enero de 1980, VIIl, p. 152.

68. P. Martínez Sáiz, "A propósito de la homilía dialogada" en Pastoral Misionera 1 (1970) pp. 41-69.

69. Cfr. Homilia, 16 de septiembre de 1979. VII, p. 257. 
es testigo fiel de su pueblo, porque ha dialogado directamente con él conoce sus sufrimientos y es su interlocutor más cualificado. Todas las estructuras de la arquidiocesis se convierten para Monseñor Romero en mecanismos de diálogo ya sea con sus colaboradores, con los agentes de pastoral o con el pueblo.

Además de este diálogo lundamental, para preparar sus homilías, Monseñor Romero se asesoraba de un equipo de colaboradores, lo cual es también otra forma de dialogar con la realidad y con el pueblo. Monseñor Romero trabajaba en equipo. En su diario pastoral podemos comprobar cómo se reunía los sábados por la mañana o por la noche con un equipo de colaboradores con quienes analizaba los acontecimientos más destacados de la semana, ya sea desde el punto de vista jurídico, sociológico, teológico o pastoral70.

De entre las muchas citas que podemos ofrecer para sustanciar lo que estamos diciendo, hay una que muestra cabalmente el esplritu de diálogo de Monseñor Romero. El quiere ponerse a preparar su homilía, pero ve trastocados sus planes por la solicitud de unos campesinos que lo invitan a bendecir una imagen. Monseñor Romero accede y luego regresa a preparar su homilía. Veamos cómo lo cuenta él:

Este día, aunque quise dedicarlo enteramente a la preparación de mi homilía del domingo, tuve que ir a catedral por la mañana a cumplir un compromiso de bendecir la imagen de san Rafael que van a llevar para el cantón de ese nombre en la parroquia de Candelaria de Cuscallán. Allá la recibirá el padre Interiano, pero no quise negarme a esta petición de los humildes campesinos, ya que en ellos siempre siento la presencia y el llamamiento de Dios... Regresé a preparar mi homilía, escuchando los asesoramientos de quienes se reúnen conmigo este día: el padre Moreno, la señorita Doris Osegueda, el licenciado Cuéllar, el padre Cortés y el padre Umutia. Me dan elementos muy valiosos para conocer mejor la realidad de la semana y saberla iluminar evangélicamente desde la homilfa dominical. He llegado hasta horas de la madrugada, ya es domingo 17 de febrero 7 .

Tres cosas debemos subrayar en esta cita. Monseñor Romero no se niega al encuentro con los campesinos, los más pobres, en quienes siempre siente la presencia y el llamamiento de Dios. Monseñor Romero prepara sus homilías con el asesoramiento de un equipo. Monseñor Romero dedica muchas horas a la preparación de las homilías.

70. Cfr. Monseñor Oscar Amulfo Romero, su diario, Arobispado de San Salvador, 1990, pp. 97, 102, 127, 134, 147, 152, 163, 187, 195, 209, 216, 229, 235, 239, 259 . $277,284,291,308,321-322,330,342,352-353,370,385-386,392,402,421,430$, 442,450 y 463.

71. Ibid., pp. 428-430. 
Este testimonio de su diario nos ayuda a comprender que la profundidad y transcendencia de sus homilías no son casuales. Son el fruto de una arraigada espiritualidad de la pobreza, de un riguroso trabajo en equipo, de una dedicación esforzada y sacrificada. Y todo ello porque Monseñor Romero dio mucha importancia a la preparación de sus homilías, como él mismo nos lo dice:

Mi predicación es un servicio a la palabra de Dios para transmitirla al pueblo. De ahí mi empeño en preparar lo mejor que puedo con mis pobres alcances esta homilía, todas mis intervenciones, mis escritos, para transmitir la palabra tratando de hacerla lo más nítida posible (Homilia, 23 de abril de 1978, IV, p. 189).

\section{2. El mélodo de preparación de la homilía}

Cuando algunos católicos conservadores y ligados a la oligarquía pidieron al Vaticano la destitución de Monseñor Romero como arzobispo, él respondió en su homilía con unas palabras que nos revelan el método que segufa para prepararlas, método que es reflejo de su teología de la salvación. La coherencia del contenido de sus homillas refleja la claridad con que procedía en la preparación. Sus homilías jamás fueron improvisadas. Y así lo dice él mismo en unas breves líneas dentro de un largo párafo que transcribimos f́ntegro por la seriedad de la ocasión:

Lo que me interesa más es esto: que estas firmas también piden mi destitución. Yo no tengo inconveniente en ser destituido ni tengo ambiciones en el poder de la diocesis, simplemente considero que esto es un servicio y que, mientras el Señor por medio del pontífice me mantenga en él, seré fiel a mi conciencia a la luz del evangelio, que es lo que yo trato de predicar, nada más ni nada menos. Porque ya entramos precisamente en materia, para que vean cuál es mi oficio y cómo lo estoy cumpliendo: estudio la palabra de Dios que se va a leer el domingo, miro a mi alrededor, a mi pueblo, lo ilumino con esta palabra y saco una síntesis para podérsela transmitir y hacerlo, a este pueblo, luz del mundo, que se deje guiar por los criterios no de las idolatrías de la tierra. Y por eso, naturalmente, que los ídolos de la tierra y las idolatrfas de la tierra sienten un estorbo en esta palabra y les interesa mucho más que la destituyeran, que la callaran, que la mataran. Suceda lo que Dios quiere, pero su palabra -decía san Pablo- no está amarrada. Habrá profetas, sacerdotes o laicos, ya los hay abundantemente, que van comprendiendo lo que Dios quiere por su palabra y para nuestro pueblo (Homilía, 20 de agosto de 1978, V, p. 135).

En este texto descubrimos por lo menos cuatro pasos en la preparación de las homilías, y en la siguiente cita menciona un quinto paso, que también es importante. Citémosla nuevamente para completar todo el proceso: 
Yo sé que hay muchos que se escandalizan de esta palabra y quieren acusarla de que ha dejado la predicación del evangelio para meterse en política. Pero no acepto yo esta acusación, sino que hago un esfuerzo para que todo lo que nos han querido impulsar el concilio Vaticano I, la reunión de Medellín y de Puebla, no sólo lo tengamos en las páginas y lo estudiemos teóricamente, sino que lo vivamos y lo traduzcamos en esta conflictiva realidad de predicar como se debe el evangelio para nuestro pueblo. Por eso, le pido al Señor durante la semana, mientras voy recogiendo el clamor del pueblo y el dolor de tanto crimen, la ignominia de tanta violencia, que me dé la palabra oportuna para consolar, para denunciar, para llamar al arrepentimiento, y aunque siga siendo una voz que clama en el desierto, sé que la Iglesia está haciendo el esfuerzo por cumplir con su misión (Homilía, 23 de marzo de 1980, VIII, p. 359).

Podemos ordenar ahora los pasos de la preparación de la homilfa:

(a) Lectura de la palabra de Dios: "Estudio la palabra de Dios que se va a leer el domingo".

(b) Lectura de la realidad histórica: "Miro a mi alrededor, a mi pueblo". "Mientras voy recogiendo el clamor del pueblo".

(c) Encarnación de la palabra de Dios en la realidad del pueblo: "Lo ilumino con esta palabra".

(d) Elaboración de un guión homilético: "Y saco un síntesis para podérsela transmitir".

(e) Oración: "Le pido al Señor... que me dé la palabra oportuna para consolar, para denunciar, para llamar al arrepentimiento".

Podemos decir, pues, que hay una preparación remota de la homilía y una preparación inmediata. Monseñor Romero, durante la semana, "va recogiendo el clamor del pueblo". Es entonces cuando se comienza a gestar su predicación, cuando hace suyo el clamor de los pobres, cuando interioriza sus problemas y esperanzas. La preparación inmediata es el tiempo especffico que Monseñor Romero ocupa para confrontar esa visión de la realidad y ese clamor del pueblo con la palabra de Dios, tiempo que, como ya queda dicho, era el día sábado.

Monseñor Romero se esfuerza por estar al dí en la exégesis błblica, en la reflexión teológica72 y en la doctrina de la Iglesia para poder iluminar en profundidad la realidad histórica de su pueblo. La exégesis actualizada, su profunda teologla y las abundantess citas y aplicación de los documentos de la Iglesia que sus homilías nos ofrecen dan prueba más que sucifiente de ello.

72. Cfr. Homilía, 24 de julio de 1977, I-II, p. 141; 25 de septiembre de 1977, I-II, p. 239. 
La asesoría de sus colaboradores la orientaba a comprender la realidad y no solamente a tener una visión panorámica de la misma. Monseñor Romero no se conforma con constatar lo que está sucediendo, quiere saber por qué suceden tales hechos y qué consecuencias traen. Los análisis de la realidad que nos ofrece sobre todo en sus últimas homilías son una muestra de objetividad y rigor.

Meditar la palabra de Dios y analizar la realidad para ponerlas en contacto es el paso fundamental de la preparación de la homilía, donde propiamente toma cuerpo la homilía.

Cuando Monseñor Romero habla de "sacar una síntesis" se refiere probablemente al esquema homilético, guión que leía al comienzo de la homilía. Monseñor no escribía sus homilías. Es posible que sobre el ambón sólo tuviera el guión y la documentación que citaría, como son cartas de la gente, citas de documentos de la Iglesia, documentos de instituciones, listas de personas desaparecidas o capturadas, etc.

Y finalmente, la oración. Monseñor Romero sabe que la preparación esforzada y rigurosa de la homilía es necesaria, pero no es suficiente: falta el encuentro personal con Dios. Monseñor Romero, que ha recogido el clamor del pueblo y los signos de los tiempos y los ha confrontado e iluminado con la Sagrada Escritura y con la doctrina de Iglesia, coloca todo frente a Dios y le pide "la palabra oportuna". Sus homilfas son palabras desde el clamor del pueblo y desde el silencio de la oración:

Ayer, cuando un periodista me preguntaba dónde encontraba yo mi inspiración para mi trabajo y mi predicación, le decía: es bien oportuna su pregunta porque cabalmente vengo saliendo de mis ejercicios espirituales. Si no fuera por esta oración y esta reflexión que trato de mantener unido con Dios, no sería yo más que lo que dice san Pablo, una lata que suena (Homilia, 2 de marzo de 1980, VIII, p. 297).

Nunca sabremos lo que sucedía en dicha oración, pero sí sabemos que Monseñor Romero pasaba largas horas orando, sobre todo cuando la situación del país era muy grave y su palabra era esperada con expectación.

Una buena preparación de la homilía, para que ésta contenga verdad y revelación, ha de seguir los pasos que Monseñor Romero nos enseñó. Predicar es algo serio y no puede ser tomado como una actividad rutinaria y superficial.

\section{Conclusión}

El modelo homilético que Monseñor Romero nos propone no es un modelo más entre otros posibles. Es el único posible para que la predicación sea verdaderamente cristiana, una predicación que es prolongación de la salvación de Dios en la historia presente. En sus homilias transcendencia e historia, doctrina 
y profecía, constituyen una perfecta unidad que hace de su palabra una palabra que salva. Insistimos en que este modelo homilético, explicar doctrinalmente la palabra de Dios y aplicarla proféticamente en la historia presente, es el único modelo posible, el único que es coherente con el mensaje que se anuncia, el misterio de salvación. Y dicho sea de paso, el único que se apega a lo que el magisterio de la Iglesia enseña que debe ser la predicación. Otra cosa es el talante personal que cada predicador imprime a su predicación, que sin duda depende de su personalidad y psicología. Podrán cambiar, pues, los predicadores, pero lo que no debe cambiar es el contenido de la predicación y el método de exponer esa predicación.

Monseñor Romero fue asesinado al pie del altar. Literalmente, murí́ predicando. Sería triste que con él también muriera su principal legado: sus homilías. No hay duda de que Monseñor Romero imprimí́ un talante personal a su predicación, pero lo que debe prevalecer no es ese talante, el cual obviamente es irrepetible. Lo que debe prevalecer es su método, porque éste está enraizado en la teología de la salvación y en el magisterio de la Iglesia.

Su método une lo que Dios nunca quiso separar, la salvación y la historia, el reino de Dios y el mundo, el pasado y el presente, la docırina y la realidad, la palabra y las obras, de modo que no es legítimo apelar al estilo de cada predicador para justificar un método diferente. Cualquier otro método sólo puede caer en un craso error de reduccionismo de la fe y de la doctrina cristiana. No es legímito apelar a aquello de que "cada maestrillo tiene su librillo". Lo central del contenido y del método de predicación no puede cambiar con cada predicador. "El tema no lo inventa el que predica"73, decía Monseñor Romero, lo impone Dios que habla desde la realidad.

El predicador, todo predicador, debe apegarse al único libro que tiene en sus manos: la Sagrada Escritura, que, con las directrices del magisterio de la Iglesia, debe encarnar en la realidad histórica de los oyentes. Cada predicador es diferente en cuanto al talante personal, pero no en cuanto al contenido y el método de la predicación. Con esto queremos decir que todos los predicadores deben predicar como predicó Monseñor.

Terminamos con el siguiente texto de Monseñor Romero que resume en tono profético y a modo de sentencia lo que hemos expuesto a lo largo de este trabajo:

Los hechos concretos Dios nos los desprecia. Querer predicar sin referirse a la historia en que se predica no es predicar el evangelio. Muchos quisieran una predicación tan espiritualista que dejara conforme a los pecadores, que no les dijera idólatras a los que están de rodillas ante el dinero y ante el

73. Homilia, 27 de enero de 1980, VIII, p. 184. 
poder. Una predicación que no denuncia las realidades pecaminosas en las que se hace la reflexión evangélica no es evangelio. Sobran aduladores, sobran falsos profetas, sobran, en tiempos conflictivos como los nuestros, quienes tienen la pluma pagada y su palabra vendida (Homilía, 18 de febrero de 1978, VI, p. 147). 